\title{
Diversity and characterization of temperate bacteriophages induced in Pasteurella multocida from different host species
}

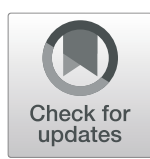

Rezheen F. Abdulrahman ${ }^{1,2}$ and Robert L. Davies ${ }^{1 *}$

\begin{abstract}
Background: Bacteriophages play important roles in the evolution of bacteria and in the emergence of new pathogenic strains by mediating the horizontal transfer of virulence genes. Pasteurella multocida is responsible for different disease syndromes in a wide range of domesticated animal species. However, very little is known about the influence of bacteriophages on disease pathogenesis in this species.

Results: Temperate bacteriophage diversity was assessed in 47 P. multocida isolates of avian (9), bovine (8), ovine (10) and porcine (20) origin. Induction of phage particles with mitomycin C identified a diverse range of morphological types representing both Siphoviridae and Myoviridae family-types in 29 isolates. Phage of both morphological types were identified in three isolates indicating that a single bacterial host may harbour multiple prophages. DNA was isolated from bacteriophages recovered from 18 P. multocida isolates and its characterization by restriction endonuclease (RE) analysis identified 10 different RE types. Phage of identical RE types were identified in certain closely-related strains but phage having different RE types were present in other closely-related isolates suggesting possible recent acquisition. The host range of the induced phage particles was explored using plaque assay but only 11 (38\%) phage lysates produced signs of infection in a panel of indicator strains comprising all 47 isolates. Notably, the majority (9/11) of phage lysates which caused infection originated from two groups of phylogenetically unrelated ovine and porcine strains that uniquely possessed the toxA gene.
\end{abstract}

Conclusions: Pasteurella multocida possesses a wide range of Siphoviridae- and Myoviridae-type bacteriophages which likely play key roles in the evolution and virulence of this pathogen.

Keywords: Pasteurella multocida, Bacteriophage diversity, Bacteriophage morphology

\section{Background}

Pasteurella multocida is a Gram-negative commensal bacterium which resides in the upper respiratory tract of mammals and birds [1]. The organism is responsible for various economically important diseases in a wide range of domestic animal species [1]. It causes fowl cholera in poultry [1-3], haemorrhagic septicaemia in cattle and

\footnotetext{
* Correspondence: Robert.Davies@glasgow.ac.uk

'Institute of Infection, Immunity and Inflammation, College of Medical, Veterinary and Life Sciences, Sir Graeme Davies Building, University of Glasgow, 120 University Place, Glasgow G12 8TA, UK

Full list of author information is available at the end of the article
}

water buffalo [4], atrophic rhinitis of pigs [5-7], pneumonia in cattle, sheep and pigs $[5,8,9]$, snuffles of rabbits [10] and septicaemia in neonatal lambs [11, 12]. Infection with $P$. multocida may also occur in humans following dog and cat bites or scratches [13-15]. Pasteurella multocida possesses a broad range of virulence factors that play important roles in disease pathogenesis and which include capsule, lipopolysaccharide and outer membrane proteins [16]. Specific virulence-associated genes also thought to be involved in the pathogenesis of $P$. multocida include tbpA, pfhA, toxA, hgbB, hgbA, nanH, nanB, sodA, sodC, oma87and ptfA [16, 17].

(c) The Author(s). 2021 Open Access This article is licensed under a Creative Commons Attribution 4.0 International License, which permits use, sharing, adaptation, distribution and reproduction in any medium or format, as long as you give appropriate credit to the original author(s) and the source, provide a link to the Creative Commons licence, and indicate if changes were made. The images or other third party material in this article are included in the article's Creative Commons licence, unless indicated otherwise in a credit line to the material. If material is not included in the article's Creative Commons licence and your intended use is not permitted by statutory regulation or exceeds the permitted use, you will need to obtain permission directly from the copyright holder. To view a copy of this licence, visit http://creativecommons.org/licenses/by/4.0/ The Creative Commons Public Domain Dedication waiver (http://creativecommons.org/publicdomain/zero/1.0/) applies to the data made available in this article, unless otherwise stated in a credit line to the data. 
Bacteriophages play important roles in the evolution of bacteria and in the emergence of new strains; in particular, they are involved in the transfer of a wide range of virulence genes and can strongly influence the pathogenic potential of bacteria [18-24]. Temperate bacteriophages are those which become integrated into the bacterial chromosome to become a prophage [25] and, in the process, may induce a change in the phenotype of the infected bacterium in a process called lysogenic conversion [26]. Those temperate bacteriophages that carry virulence genes may transform a bacterial host from a commensal to a pathogenic strain and can contribute significantly to bacterial virulence [27-30]. Toxins represent an important class of virulence genes that are transferred by bacteriophages $[18,19,31]$, but phage also encode genes involved in adhesion, colonisation, immune evasion and serum resistance, as well as the expression of surface-exposed antigens [18, 25, 28, 31, 32]. The presence of these genes within phage genomes suggests that there is an evolutionary advantage for the bacteriophages to carry such genes, perhaps due to enhanced replication of bacteria carrying these virulence determinants [31].

Very little is known about the temperate bacteriophages of $P$. multocida and their potential role in the virulence and evolution of this pathogen. Bacteriophages have been described in P. multocida and used as a typing method in epidemiological studies [33, 34]. The morphology of temperate phage in a small number of $P$. multocida isolates has been described and a diverse group of phage belonging to the Myoviridae, Siphoviridae and Podoviridae families identified [35]. Certain porcine strains of $P$. multocida responsible for atrophic rhinitis produce a mitogenic toxin (PMT) that is encoded by the tox $A$ gene; notably, toxA is associated with a lysogenic Siphoviridae-type bacteriophage [36]. However, toxA has also more recently been identified in ovine $P$. multocida isolates $[17,37,38]$, suggesting a role for bacteriophages in the horizontal transfer of tox $A$ from porcine to ovine strains.

The diversity of temperate bacteriophages associated with $P$. multocida strains of known genetic relatedness and originating from different host species and disease syndromes has not previously been assessed. In the present study, we aimed to investigate the presence and diversity of temperate bacteriophages within a collection of $P$. multocida strains recovered from avian, bovine, ovine and porcine hosts with a longer-term view of assessing whether bacteriophages are contributing to the evolution of P. multocida in these different host species. To achieve these aims, bacteriophages were induced in 47 P. multocida isolates carefully selected to represent specific phylogenetic lineages, host species of origin, disease types, capsular serotypes and OMP-types. Bacteriophages were induced using mitomycin $\mathrm{C}$ which has commonly been used for bacteriophage induction in a wide range of bacterial species [39-42] including $P$. multocida [33, 36, 43]. The induced bacteriophages were subsequently characterized by assessing their morphologies using transmission electron microscopy (TEM) and examining their genetic relatedness using DNA restriction endonuclease (RE) analysis. In addition, the host range of selected bacteriophages was assessed against a panel of indicator strains comprising all $47 \mathrm{P}$. multocia isolates.

\section{Results}

\section{Bacteriophage induction}

Mitomycin C is commonly used to induce temperate bacteriophages in bacteria and typically causes lysis of the bacteria which results in clearing of the bacterial suspension over time. However, the rate and degree of lysis can vary according to the properties and density of the induced phage $[44,45]$. To identify the optimum concentration of mitomycin $\mathrm{C}$ required to induce temperate bacteriophages in P. multocida isolates, seven different concentrations were tested against eight strains of avian (PM144, PM246), bovine (PM564, PM632), ovine (PM966, PM982) and porcine (PM684, PM734) origin. These strains represent various capsular serotypes, OMP types and multilocus sequence types (STs) and their properties are shown in Table 1. The $\mathrm{OD}_{600}$ values were plotted against time (h) for the control and seven different mitomycin C concentrations for each isolate and three general patterns were observed; these were designated complete lysis, partial lysis or reduced growth, and no lysis or no reduced growth (Fig. S1). Isolates PM684 and PM982 were highly sensitive to mitomycin $\mathrm{C}$ treatment compared to the other isolates and underwent rapid and complete lysis by $0.2 \mu \mathrm{g} / \mathrm{ml}$ mitomycin $\mathrm{C}$ (Fig. S1A \& B). The growth of isolates PM246, PM632, PM734 and PM966 was progressively reduced as the mitomycin $\mathrm{C}$ concentration increased; however, complete lysis, as observed with PM684 and PM982, was not achieved even at the highest concentration of mitomycin C (Fig. S1C-F). Isolates PM144 and PM564 exhibited little or no effect from mitomycin C although the final $\mathrm{OD}_{600}$ values, even for the controls, were not as high as for the other six isolates (Fig. S1G \& H). Overall, the results demonstrated that final concentrations of $0.2,0.5,1.0$ and $2.0 \mu \mathrm{g} / \mathrm{ml}$ can be used for assessing induction of temperate phage in $P$. multocida. However, a concentration of $0.2 \mu \mathrm{g} / \mathrm{ml}$ 
Table 1 Details of 47 P. multocida isolates

\begin{tabular}{|c|c|c|c|c|c|c|c|c|c|}
\hline Isolate $^{a}$ & $\begin{array}{l}\text { Host } \\
\text { species }\end{array}$ & Disease syndrome & $\begin{array}{l}\text { Isolation } \\
\text { site }\end{array}$ & $\begin{array}{l}\text { MLST } \\
\text { lineage }\end{array}$ & $\mathrm{ST}^{\mathrm{b}}$ & $\begin{array}{l}\text { Capsular } \\
\text { type }\end{array}$ & $\begin{array}{l}\text { OMP- } \\
\text { type }\end{array}$ & $\begin{array}{l}\text { tox } A \\
\text { gene }\end{array}$ & $\begin{array}{l}\text { Indicator strain group } \\
\text { (ISG) }\end{array}$ \\
\hline PM316 & Bovine & Pneumonia & Lung & A & 1 & A & 1.1 & ND & $1 a$ \\
\hline PM564 & Bovine & Pneumonia & Lung & A & 1 & A & 2.1 & $N D^{d}$ & $1 a$ \\
\hline PM344 & Bovine & Pneumonia & Lung & A & 3 & A & 3.1 & ND & $2 a$ \\
\hline PM632 & Bovine & Pneumonia & Lung & A & 4 & A & 4.1 & ND & $2 b$ \\
\hline PM666 & Porcine & Pneumonia & Lung & A & 3 & A & 2.1 & - & $2 b$ \\
\hline PM116 & Porcine & Pleuropneumonia & Lung & A & 3 & A & 3.1 & - & $2 b$ \\
\hline PM966 & Ovine & Pneumonia & Lung & B & 16 & A & 1.1 & - & \\
\hline PM382 & Porcine & Respiratory problems & Lung & C & 13 & A & 4.1 & - & \\
\hline PM706 & Porcine & Pneumonia & Lung & C & 13 & UT & 4.1 & - & \\
\hline PM2 & Ovine & Severe peritonitis & - & C & 17 & $\mathrm{~F}$ & 2.1 & - & \\
\hline PM8 & Ovine & Asymptomatic & Vagina & C & 17 & $\mathrm{~F}$ & 2.1 & - & \\
\hline PM246 & Avian & Septicaemia & Viscera & C & 25 & $\mathrm{~F}$ & 2.2 & ND & \\
\hline PM994 & Ovine & Pneumonia & Lung & C & 12 & $\mathrm{~F}$ & 1.1 & - & \\
\hline PM148 & Avian & Eye infection & Eye & C & 12 & $F$ & 2.2 & ND & \\
\hline PM104 & Avian & Septicaemia & Liver/spleen & D & 28 & A & 4.1 & ND & \\
\hline PM86 & Avian & Fowl cholera & Pleura & D & 15 & A & 3.1 & ND & $3 a$ \\
\hline PM934 & Porcine & Pneumonia & Lung & D & 15 & A & 5.1 & - & $3 a$ \\
\hline PM954 & Porcine & Pneumonia & Lung & D & 15 & A & 5.1 & - & $3 a$ \\
\hline PM486 & Bovine & Pneumonia & $\begin{array}{l}\text { Lung } \\
\text { abscess }\end{array}$ & D & 9 & A & 9.1 & ND & $3 a$ \\
\hline PM172 & Avian & Septicaemia & Lung & D & 26 & A & 3.1 & ND & $3 a$ \\
\hline PM302 & Bovine & Rhinitis + others & Nasal swab & $\mathrm{E}$ & 6 & A & 5.3 & ND & $3 b$ \\
\hline PM144 & Avian & Septicaemia & Lung/liver & $E$ & 21 & A & 1.1 & ND & \\
\hline PM402 & Bovine & Pneumonia & Lung & $E$ & 5 & A & 5.1 & ND & \\
\hline PM122 & Ovine & Pneumonia & Lung & ND & $N D$ & D & 3.1 & + & \\
\hline PM964 & Ovine & Pneumonia & Lung & $\mathrm{E}$ & 18 & D & 3.1 & + & \\
\hline PM982 & Ovine & Pneumonia & Lung & $\mathrm{E}$ & 18 & D & 3.1 & + & \\
\hline PM986 & Ovine & Pneumonia & Lung & $E$ & 18 & D & 3.1 & + & \\
\hline PM988 & Ovine & Pasteurellosis & Lung & ND & $\mathrm{ND}$ & D & 3.1 & + & \\
\hline PM990 & Ovine & Pneumonia & Lung & ND & $N D$ & D & 3.1 & + & \\
\hline PM54 & Porcine & Pneumonia & Lung & $\mathrm{F}$ & 10 & A & 1.1 & - & 4 \\
\hline PM734 & Porcine & Pneumonia & Lung & $\mathrm{F}$ & 10 & A & 1.1 & - & 4 \\
\hline PM820 & Porcine & Pneumonia & Lung & $\mathrm{F}$ & 10 & A & 1.1 & - & 4 \\
\hline PM850 & Porcine & Pneumonia & Lung & $\mathrm{F}$ & 10 & A & 1.1 & - & 4 \\
\hline PM200 & Avian & Pneumonia & Lung & $\mathrm{F}$ & 10 & A & 1.2 & ND & \\
\hline PM336 & Bovine & Pneumonia & Lung & $\mathrm{F}$ & 7 & A & 6.1 & ND & $1 b$ \\
\hline PM684 & Porcine & $\begin{array}{l}\text { Suspected atrophic } \\
\text { rhinitis }\end{array}$ & Nasal swab & G & 11 & A & 6.1 & + & 5 \\
\hline PM918 & Porcine & Pneumonia & Lung & G & 11 & A & 6.1 & + & 5 \\
\hline PM926 & Porcine & Pneumonia & Lung & ND & $N D$ & A & 6.1 & + & 5 \\
\hline PM40 & Porcine & - & - & ND & ND & A & 6.2 & + & 5 \\
\hline PM716 & Porcine & $\begin{array}{l}\text { Suspected atrophic } \\
\text { rhinitis }\end{array}$ & Nasal swab & G & 11 & D & 4.1 & + & \\
\hline PM848 & Porcine & Pneumonia & Lung & G & 11 & D & 4.1 & + & \\
\hline
\end{tabular}


Table 1 Details of 47 P. multocida isolates (Continued)

\begin{tabular}{|c|c|c|c|c|c|c|c|c|c|}
\hline Isolate $^{a}$ & $\begin{array}{l}\text { Host } \\
\text { species }\end{array}$ & Disease syndrome & $\begin{array}{l}\text { Isolation } \\
\text { site }\end{array}$ & $\begin{array}{l}\text { MLST } \\
\text { lineage }\end{array}$ & $\mathrm{ST}^{\mathrm{b}}$ & $\begin{array}{l}\text { Capsular } \\
\text { type }\end{array}$ & $\begin{array}{l}\text { OMP- } \\
\text { type }\end{array}$ & $\begin{array}{l}\text { toxA } \\
\text { gene }\end{array}$ & $\begin{array}{l}\text { Indicator strain group } \\
\text { (ISG) }\end{array}$ \\
\hline PM696 & Porcine & $\begin{array}{l}\text { Suspected atrophic } \\
\text { rhinitis }\end{array}$ & Nasal swab & G & 11 & $\mathrm{D}$ & 6.1 & + & \\
\hline PM714 & Porcine & Pneumonia & Lung & G & 11 & $\mathrm{D}$ & 6.1 & - & \\
\hline PM762 & Porcine & Atrophic rhinitis & Turbinate & G & 11 & $\mathrm{D}$ & 6.1 & + & \\
\hline PM890 & Porcine & $\begin{array}{l}\text { Suspected atrophic } \\
\text { rhinitis }\end{array}$ & Nasal swab & G & 11 & $\mathrm{D}$ & 6.1 & + & \\
\hline PM226 & Avian & Pneumonia/death & Lesion & G & 11 & D & 13.1 & - & \\
\hline PM82 & Avian & Swollen heads & Peritoneal & $\mathrm{H}$ & 32 & A & 7.1 & ND & \\
\hline
\end{tabular}

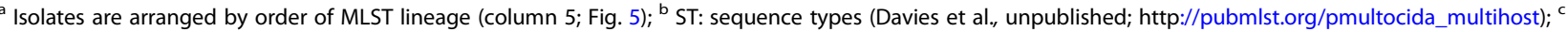
OMP-types for bovine, ovine, porcine and avian isolates have been defined previously $[9,46-49]$ and are not equivalent, i.e. bovine OMP-type 1.1 is not as same as porcine OMP-type 1.1, etc.; ${ }^{d}$ ND: not determined

mitomycin $\mathrm{C}$ was selected as optimum because this concentration was sufficient to cause complete and rapid bacterial cell lysis in isolates PM684 and PM982.

The induction profiles of 47 isolates of $P$. multocida from the four host species and representing various capsular serotypes, OMP-types, and STs were subsequently generated first using $0.2 \mu \mathrm{g} / \mathrm{ml}$ mitomycin $\mathrm{C}$. In the absence of lysis with the $0.2 \mu \mathrm{g} / \mathrm{ml}$ mitomycin $\mathrm{C}$, the effect of using higher concentrations of $0.5,1.0$ and $2.0 \mu \mathrm{g} /$ $\mathrm{ml}$ was assessed. In this way, the 47 isolates were assigned to one of the three induction profiles described above: complete lysis, partial lysis or reduced growth, and no lysis or no reduced growth. An example of each induction profile type is shown in Fig. 1. Taking the 47 isolates into account, complete lysis was characterized by a rapid decrease in optical density which typically attained a final $\mathrm{OD}_{600}$ value of $<$ 0.4 (Fig. 1a); partial lysis or reduced growth was characterized by a gradual decrease in optical density or flattening of the curve which typically attained a final $\mathrm{OD}_{600}$ value of $>$ 0.4 (Fig. 1b); and no lysis or no reduced growth was characterized by no or little observable difference between the mitomycin C-treated cultures and the controls (Fig. 1c). The induction profiles assigned to the 47 isolates are summarised in Table S1. The majority (37/47) of the strains were either completely or partially lysed with $0.2 \mu \mathrm{g} / \mathrm{ml}$ mitomycin $\mathrm{C}$, although a proportion of isolates required exposure to higher concentrations of mitomycin $\mathrm{C}$ (ranging from 0.5 to $2.0 \mu \mathrm{g}$ / $\mathrm{ml}$ ) to induce either partial or complete lysis. Fifteen (32\%) isolates exhibited complete lysis, 22 (47\%) were partially lysed or showed reduced growth, and 10 (21\%) showed no lysis or no reduced growth even after exposure to $2.0 \mu \mathrm{g} / \mathrm{ml}$ mitomycin $\mathrm{C}$ for $24 \mathrm{~h}$. Ten isolates that initially exhibited no signs of lysis with $0.2 \mu \mathrm{g} / \mathrm{ml}$ mitomycin $\mathrm{C}$ were subsequently shown to be induced by higher concentrations of mitomycin $\mathrm{C}$ (Table S1).

\section{Bacteriophage morphology by TEM}

Triplicate samples of cultures representing each isolate were subjected to mitomycin $\mathrm{C}$ treatment and the cultures examined by TEM. Overall, phage particles were identified in $29 \mathrm{P}$. multocida isolates that were treated with mitomycin C (Table 2). Bacteriophages were identified in 14/15 (93\%) isolates that underwent complete lysis, in 15/22 (68\%) that underwent partial lysis or reduced growth, and in none of the 10 isolates that showed no evidence of lysis or reduced growth (Table S1). Based on their tail morphologies, the phage particles identified belonged to the Siphoviridae and Myoviridae families of the order Caudovirales. Siphoviridae-like phage were induced exclusively in 18 (62.1\%) P. multocida isolates whereas Myoviridae-like phage were induced in six (20.7\%) isolates; however, both Siphoviridae- and Myoviridae-type phage were identified in three (10.3\%) isolates and tail-less capsids were identified in two (6.9\%) isolates (Table 2). Variation was observed in the morphology of the Siphoviridae-type phage; the shape and size of both the capsid and tail of phage varied between certain isolates. Thus, these phage possessed either hexagonal or elongated capsids and the head size varied from 50 to $80 \mathrm{~nm}$ long and 55 to $65 \mathrm{~nm}$ wide. The capsids were connected to flexible tails approximately 110 to $242 \mathrm{~nm}$ long and 6 to $9 \mathrm{~nm}$ in diameter (Fig. 2a \& b; Table 2). Myoviridae-type phage were characterized by the possession of hexagonal capsids 59 to $63 \mathrm{~nm}$ long and 51 to $56 \mathrm{~nm}$ wide and long contractile tails with either extended or contracted sheaths; the tails were approximately $150 \mathrm{~nm}$ long and 16 to $18 \mathrm{~nm}$ wide (Table 2). Variation was also observed in the tail ends: some had blunt ends (Fig. 2c, arrow) whereas others had prominent base plates and tail fibres (Fig. 


\section{A}

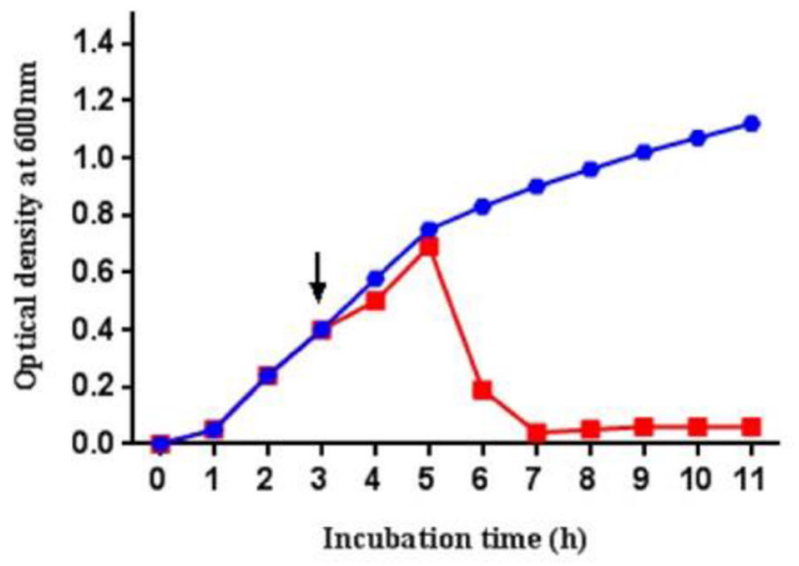

$\rightarrow 0 \mu \mathrm{g} / \mathrm{ml}$ (control)

$-0.2 \mu \mathrm{g} / \mathrm{ml}$

B

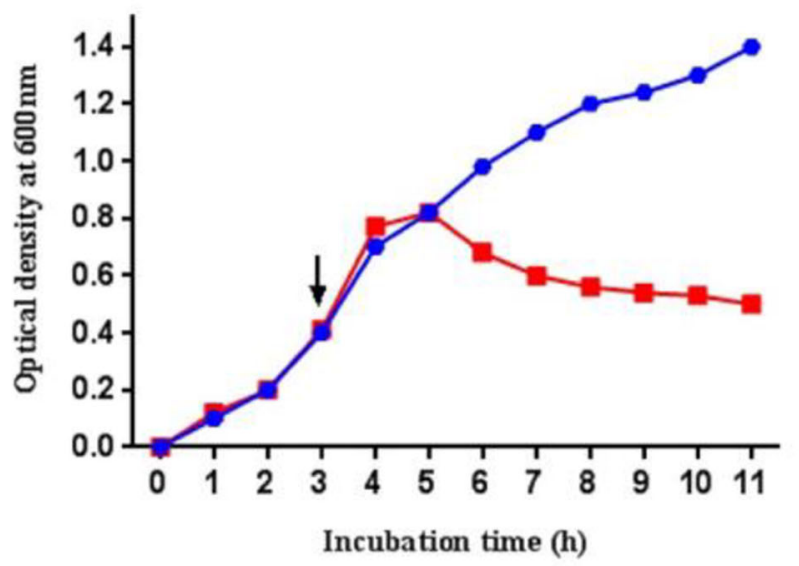

$0 \mu \mathrm{g} / \mathrm{ml}$ (control)

$0.2 \mu \mathrm{g} / \mathrm{ml}$

\section{C}

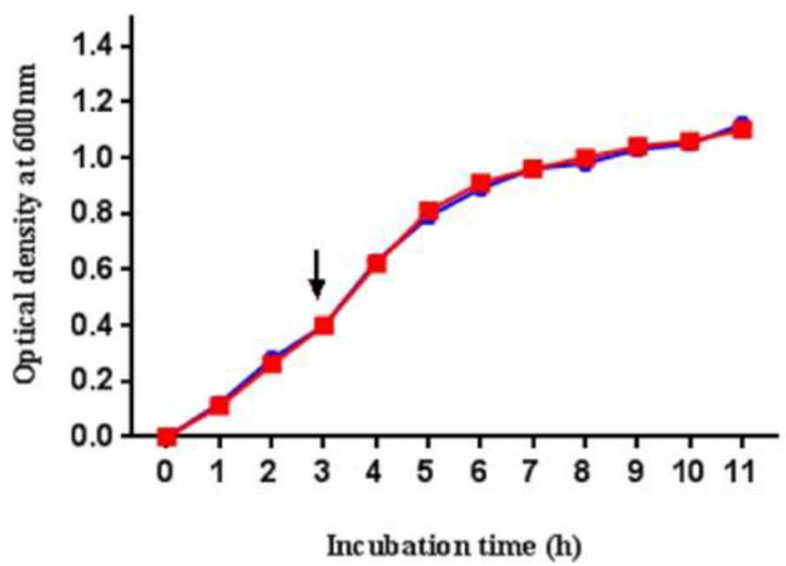

$\rightarrow 0 \mu \mathrm{g} / \mathrm{ml}$ (control)

$0.2 \mu \mathrm{g} / \mathrm{ml}$

Fig. 1 (See legend on next page.) 
(See figure on previous page.)

Fig. 1 Phage induction profiles showing (a) complete lysis, (b) partial lysis or reduced growth and (c) no lysis or no reduced growth with $0.2 \mu \mathrm{g} /$ $\mathrm{ml}$ mitomycin C. Mitomycin $\mathrm{C}$ was added once the $\mathrm{OD}_{600}$ reached 0.4 and the $\mathrm{OD}_{600}$ was plotted against time (h). The induction profile for each isolate was generated by comparing the $\mathrm{OD}_{600}$ with the control (no mitomycin $\mathrm{C}$ ) over $11 \mathrm{~h}$. The arrows indicate the points at which the mitomycin C was added. Graphs were created using GraphPad Prism 7

2d, arrow). Both Siphoviridae- and Myoviridae-type phage were identified in isolates PM86, PM684 and PM850 indicating that a single host may harbour multiple prophages (Fig. 2e, arrows; Table 2).
Notably, the five isolates PM86, PM172, PM486, PM934 and PM954 contained a distinct Myoviridaetype phage (Fig. 2f). These phage particles (discussed further below) were unique in that they possessed

Table 2 Properties of temperate bacteriophages identified in 29 P. multocida isolates

\begin{tabular}{|c|c|c|c|c|c|c|c|c|}
\hline Isolate & $\begin{array}{l}\text { Lysis } \\
\text { type }^{\mathrm{a}}\end{array}$ & $\begin{array}{l}\text { No of phage types } \\
\text { (TEM) }\end{array}$ & Family type $^{\mathrm{b}}$ & $\begin{array}{l}\text { Head size } \\
(\mathrm{nm})^{\mathrm{c}}\end{array}$ & $\begin{array}{l}\text { Tail size } \\
(\mathrm{nm})^{\mathrm{d}}\end{array}$ & $\begin{array}{l}\text { Host range group } \\
\text { (HRG) }\end{array}$ & $\begin{array}{l}\text { Phage } \\
\text { DNA }\end{array}$ & $\begin{array}{l}\mathrm{RE} \\
\text { type }\end{array}$ \\
\hline PM666 & Partial & 1 & Siphoviridae & $50 \times 55$ & $132 \times 8$ & - & - & - \\
\hline PM116 & Partial & 1 & Siphoviridae & $50 \times 56$ & $138 \times 8$ & - & - & - \\
\hline PM966 & Partial & 1 & Siphoviridae & $52 \times 58$ & $110 \times 8$ & - & - & - \\
\hline PM382 & Complete & 1 & Myoviridae & $63 \times 55$ & $147 \times 16$ & - & + & A \\
\hline PM86 & Partial & 2 & $\begin{array}{l}\text { Myoviridae \& } \\
\text { Siphoviridae }\end{array}$ & $38 \times 37 / 63 \times 55$ & $\begin{array}{l}190 \times 18 / \\
138 \times 7\end{array}$ & - & + & J \\
\hline PM934 & Partial & 1 & Myoviridae & $38 \times 37$ & $190 \times 18$ & - & + & B \\
\hline PM954 & Partial & 1 & Myoviridae & $38 \times 37$ & $190 \times 18$ & - & + & B \\
\hline PM486 & Partial & 1 & Myoviridae & $38 \times 37$ & $190 \times 18$ & - & + & B \\
\hline PM172 & Partial & 1 & Myoviridae & $39 \times 37$ & $190 \times 18$ & - & + & B \\
\hline PM122 & Complete & 1 & Siphoviridae & $66 \times 67$ & $142 \times 8$ & I & + & C \\
\hline PM964 & Complete & 1 & Siphoviridae & $62 \times 55$ & $141 \times 8$ & I & + & C \\
\hline PM982 & Complete & 1 & Siphoviridae & $63 \times 61$ & $146 \times 9$ & I & + & C \\
\hline PM986 & Complete & 1 & Siphoviridae & $64 \times 60$ & $149 \times 8$ & I & + & C \\
\hline PM988 & Complete & 1 & Siphoviridae & $64 \times 55$ & $136 \times 8$ & I & + & C \\
\hline PM54 & Partial & 1 & Siphoviridae & $54 \times 54$ & $142 \times 9$ & - & - & - \\
\hline PM820 & Partial & 1 & Siphoviridae & $54 \times 54$ & $142 \times 9$ & - & - & - \\
\hline PM850 & Complete & 2 & $\begin{array}{l}\text { Myoviridae \& } \\
\text { Siphoviridae }\end{array}$ & $59 \times 51 / 52 \times 59$ & $\begin{array}{l}148 \times 16 / \\
134 \times 8\end{array}$ & III & + & D \\
\hline PM200 & Complete & 1 & Siphoviridae & $63 \times 57$ & $138 \times 7$ & - & - & - \\
\hline PM336 & Complete & 1 & Siphoviridae & $80 \times 59$ & $154 \times 7$ & IV & + & $\mathrm{E}$ \\
\hline PM684 & Complete & 2 & $\begin{array}{l}\text { Myoviridae \& } \\
\text { Siphoviridae }\end{array}$ & $63 \times 52 / 59 \times 57$ & $\begin{array}{l}148 \times 15 / \\
125 \times 8\end{array}$ & Ila & + & $\mathrm{F}$ \\
\hline PM918 & Complete & 1 & Siphoviridae & $55 \times 65$ & $242 \times 8$ & $\| b$ & + & G \\
\hline PM926 & Complete & 1 & Siphoviridae & $66 \times 56$ & $149 \times 8$ & $\| \mathrm{b}$ & + & G \\
\hline PM40 & Complete & 1 & Myoviridae & $60 \times 56$ & $144 \times 16$ & IIC & + & $\mathrm{H}$ \\
\hline PM848 & Complete & 1 & Siphoviridae & $63 \times 61$ & $143 \times 9$ & - & + & 1 \\
\hline PM696 & Partial & 1 & Siphoviridae & $60 \times 54$ & $110 \times 7$ & - & - & - \\
\hline PM714 & Partial & 1 & Siphoviridae & $55 \times 56$ & $107 \times 6$ & - & - & - \\
\hline PM762 & Partial & 1 & Tail-less phage & $66 \times 54$ & - & - & - & - \\
\hline PM890 & Partial & 1 & Tail-less phage & $65 \times 60$ & - & - & - & - \\
\hline PM226 & Partial & 1 & Siphoviridae & $54 \times 56$ & $126 \times 8$ & - & - & - \\
\hline
\end{tabular}

${ }^{a}$ Complete lysis when the final $\mathrm{OD}_{600}$ was 0.4 or less; partial lysis when the $\mathrm{OD}_{600}$ was above 0.4 ; little or no lysis when the $\mathrm{OD}_{600}$ values in control and mitomycin $\mathrm{C}$ treated cultures remained constant after being treated with mitomycin $\mathrm{C}$ for $8 \mathrm{~h}$ of incubation. ${ }^{\mathrm{b}, \mathrm{c}}$ and ${ }^{\mathrm{d}}$ based on TEM 

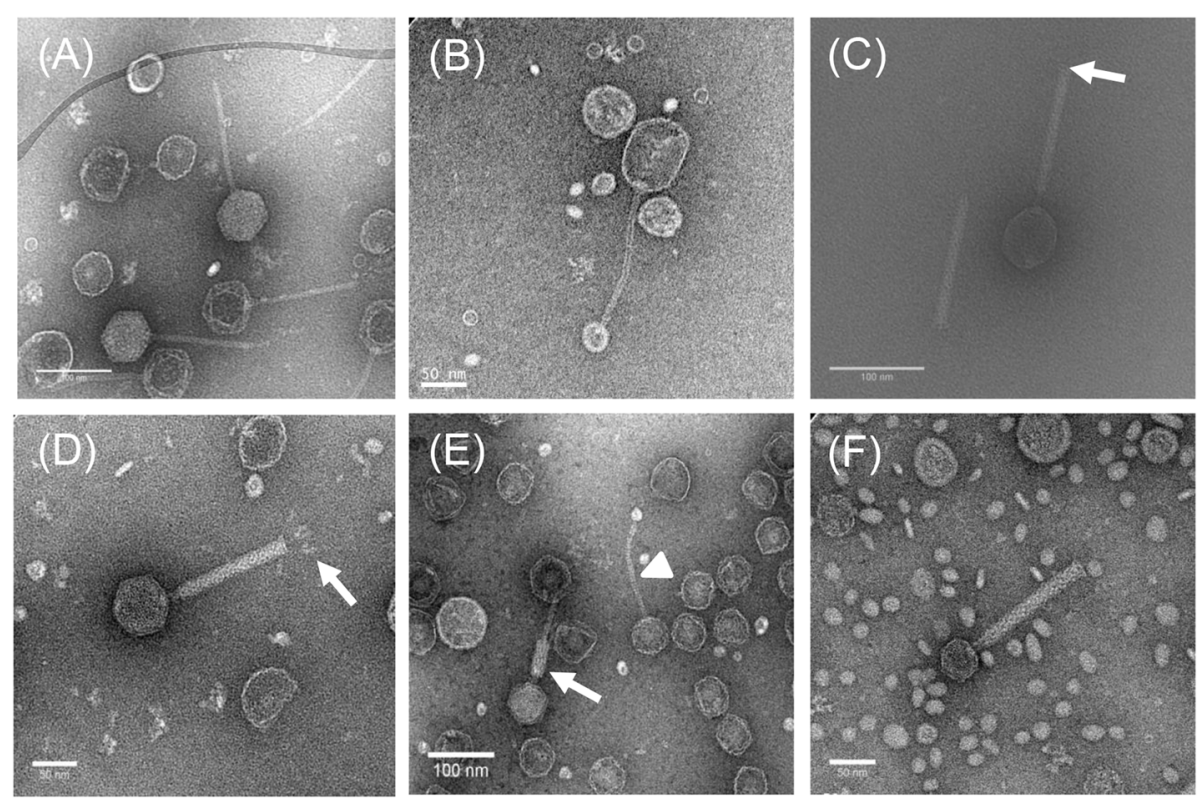

Fig. 2 Electron micrographs of phage induced in P. multocida isolates. Differences were observed in the morphology of phage induced in $P$. multocida isolates. Siphoviridae-like phage possessed hexagonal (a) or elongated (b) capsids connected to flexible tails. Differences were also observed in the morphology of Myoviridae-like phage which possessed extended sheaths and blunt ends (c; arrow), extended sheaths and prominent base plates and tail fibres (d; arrow) or contracted sheaths and blunt tail ends (e; arrow). In some cases, Myoviridae- and Siphoviridaetype phage were both induced in the same bacterial hosts (e; arrow and arrowhead). Myoviridae-type phage were also identified in a sub-set of isolates which possessed unique, small hexagonal capsids (f)

relatively small hexagonal capsid heads that were only 38 to $39 \mathrm{~nm}$ long and $37 \mathrm{~nm}$ wide; their tails were approximately $190 \mathrm{~nm}$ long and $18 \mathrm{~nm}$ wide (Table 2). Hexagonal, apparently tail-less, capsids approximately $65 \mathrm{~nm}$ diameter were observed in isolates PM762 and PM890 (images not shown).

\section{Restriction endonuclease analysis of phage DNA}

Phage DNA was successfully isolated from 18 of the 29 induced P. multocida cultures (Table 2). These isolates typically yielded large numbers of phage particles as observed by TEM. In most cases, a single band of varying intensity, demonstrating differing levels of phage induction between isolates, was identified (Fig. 3). However, two DNA bands of different molecular sizes were identified in the five isolates PM86, PM172, PM486, PM934 and PM954 suggesting the presence of at least two types of phage (Fig. 3). In preliminary RE experiments, the restriction profiles obtained with PsI, BamH1, Hind III, Ndel, EcoR1, XbaI were compared, and overnight incubation at $37^{\circ} \mathrm{C}$ with HindIII was found to yield the most informative profiles (results not shown). DNA obtained from each of the 18 phage lysates was digested with HindIII and 10 different RE profiles, designated A to J, were identified (Fig. 4). The identification of 10 different RE types in lysates obtained from only 18 isolates demonstrated that the bacteriophages of $P$. multocida are relatively diverse. The association of the RE types with the various phage and isolates of origin is summarised in Table 2 and bacterial strain characteristics are summarised in Table 1. Type A was associated with Myoviridae-type phage from porcine isolate PM382 (capsular type A; ST13; MLST lineage C); type B was associated with Myoviridae-type phage from porcine isolates PM934 and PM954, bovine isolate PM486 and avian isolate PM172, (capsular type A; STs 15, 9 and 26; MLST lineage D); type C was associated with Syphoviridae-type phage from ovine isolates PM122, PM964, PM982, PM986 and PM988 (capsular type D; ST18; MLST lineage E); type D was associated with Myoviridae- and Siphoviridae-type phage from porcine isolate PM850 (capsular type A; ST10; MLST lineage F); type E was associated with Siphoviridae-type phage from bovine isolate PM336 (capsular type A; ST7; MLST lineage F); type F was associated with Myoviridae- and Siphoviridae-type phage from porcine isolate PM684 (capsular type A; ST11; MLST lineage G); type G was associated with Siphoviridae-type phage from porcine isolates PM918 and PM926 (capsular type A; ST11; MLST lineage G); type $\mathrm{H}$ was associated with Myoviridae-type phage from porcine isolate PM40 (capsular type A); type I was associated with Siphoviridae-type phage from porcine isolate PM848 (capsular type D; ST11; MLST lineage G) and type J was associated with Myoviridaeand Siphoviridae-type phage from avian isolate PM86 (capsular type A; ST15; MLST lineage D). These results 

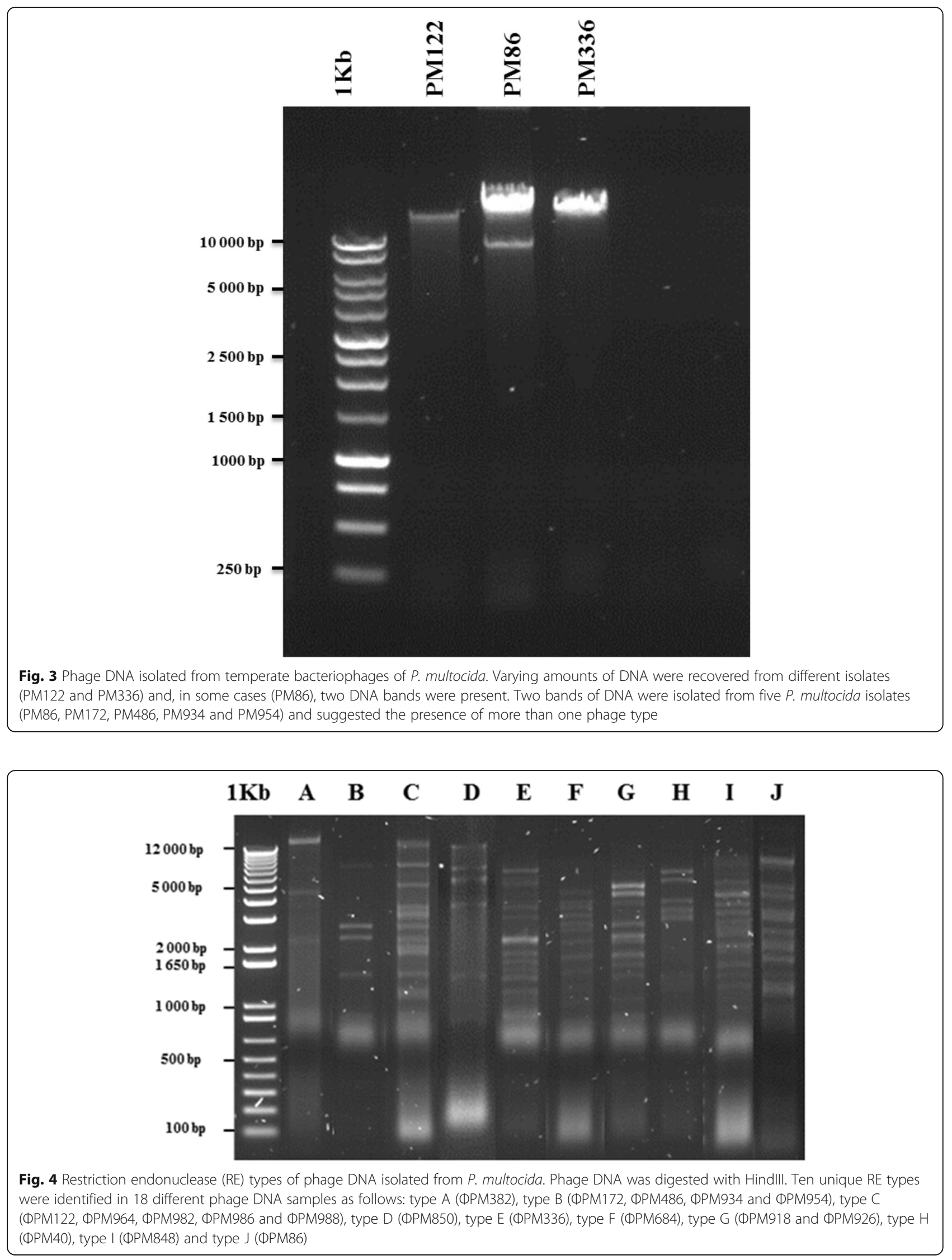


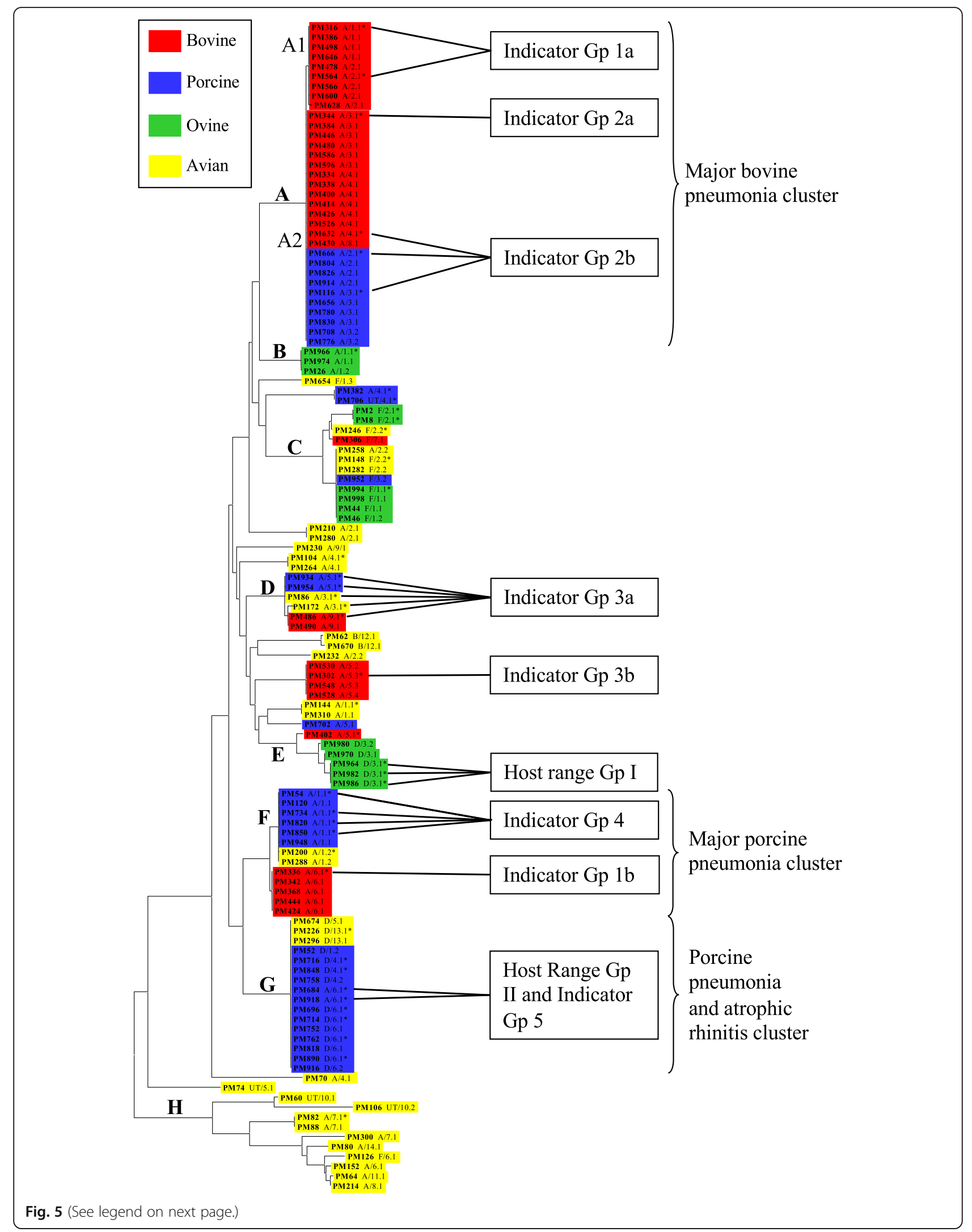


(See figure on previous page.)

Fig. 5 Phylogenetic relationships of 123 P. multocida isolates based on multilocus sequence typing (MLST). Neighbour-Joining tree representing the phylogenetic relationships of $P$. multocida strains based on the concatenated sequences (3990 bp) of seven housekeeping enzyme genes from 123 isolates of $P$. multocida of avian, bovine, ovine and porcine origin (http://pubmlst.org/pmultocida_multihost/). Isolate designations, capsular types and OMP types are provided for each isolate (e.g. PM316/A/1.1)

demonstrated that certain RE types, such as B and C, were associated with phage induced in genetically identical or closely-related P. multocida isolates (i.e. MLST lineages D and E, respectively; Fig. 5). However, in other cases, phage of different RE types, such as F, G, and I, were present in closely related strains (MLST lineage G; Fig. 5) although these did differ in capsular type, OMPtype or disease syndrome (Table 1).

\section{Host range of induced phage and indicator strain sensitivities}

The phage induced in the 29 P. multocida isolates were assessed for their abilities to infect indicator strains and to determine if there was any correlation between phage type and the ability to infect certain P. multocida strains. These experiments also provided information about the characteristics and relationships of strains that were sensitive to infecting phage. Spotting $10 \mu \mathrm{l}$ of each lysate onto the assay plates resulted in the formation of zones of lysis with certain indicator strains after overnight incubation (Fig. 6). Of the 29 phage lysates, only 11 (38\%) produced signs of infection; 18 (62\%) lysates did not produce any visible signs of infection on any of the indicator strains used (Table 3). Differences were observed in the patterns of lysis produced by various lysates and the phage were accordingly assigned to phage "lytic types" or "host range groups" (HRGs) I, IIa, IIb, IIc, III and IV (Table 3). Similarly, differences were observed in
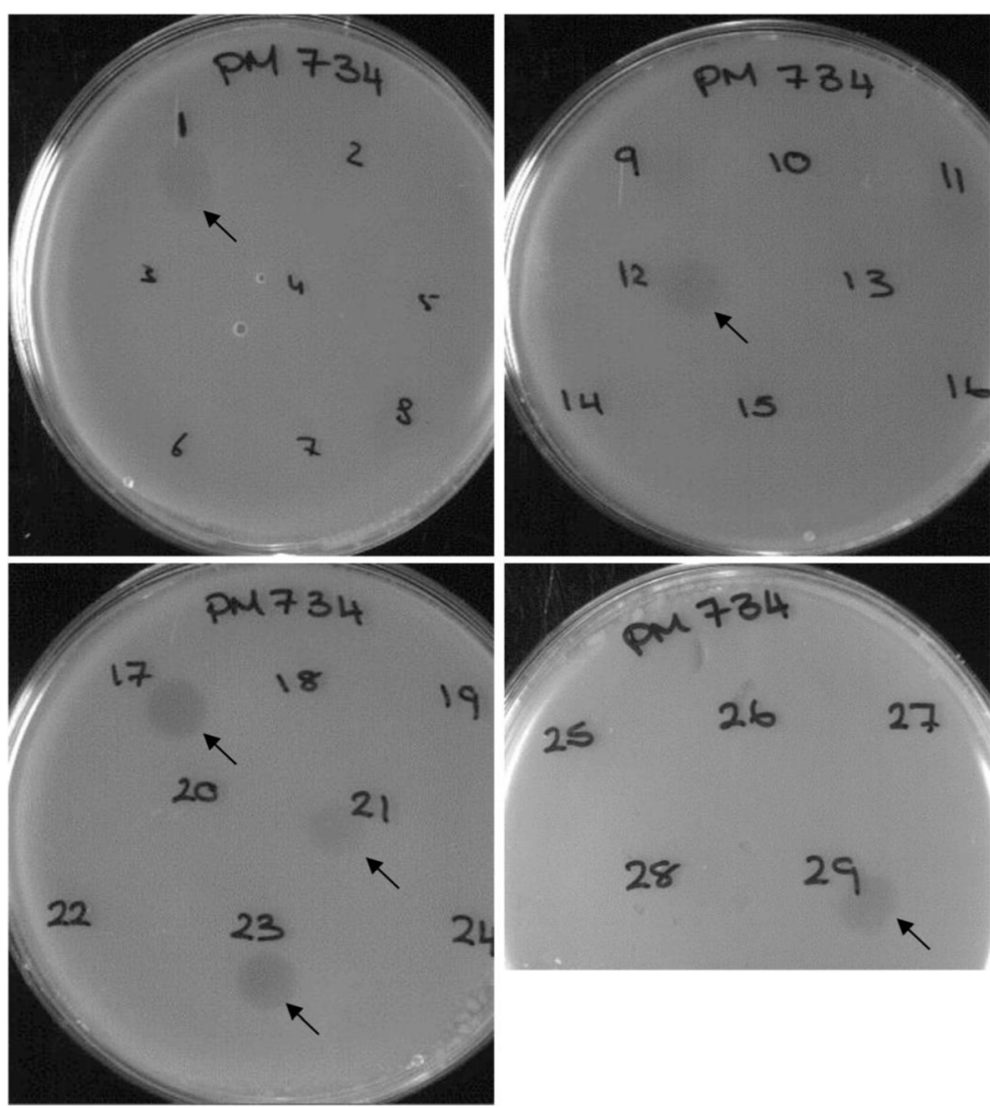

Fig. 6 Plaque assay showing the activities of 29 induced lysates against isolate PM734 as an indicator strain. Faint lysis zones were produced by ФPM850 (1), ФPM964 (12), ФPM918 (21) and DPM926 (29) (arrows), whereas ФPM684 (17) and DPM40 (23) and produced clear lysis zones (arrows). The remaining lysates did not produce any signs of infection. Numbers (1 to 29) indicate phage (lysates) produced by 29 different $P$. multocida isolates. Indicator strain designations are shown at the top of each plate 


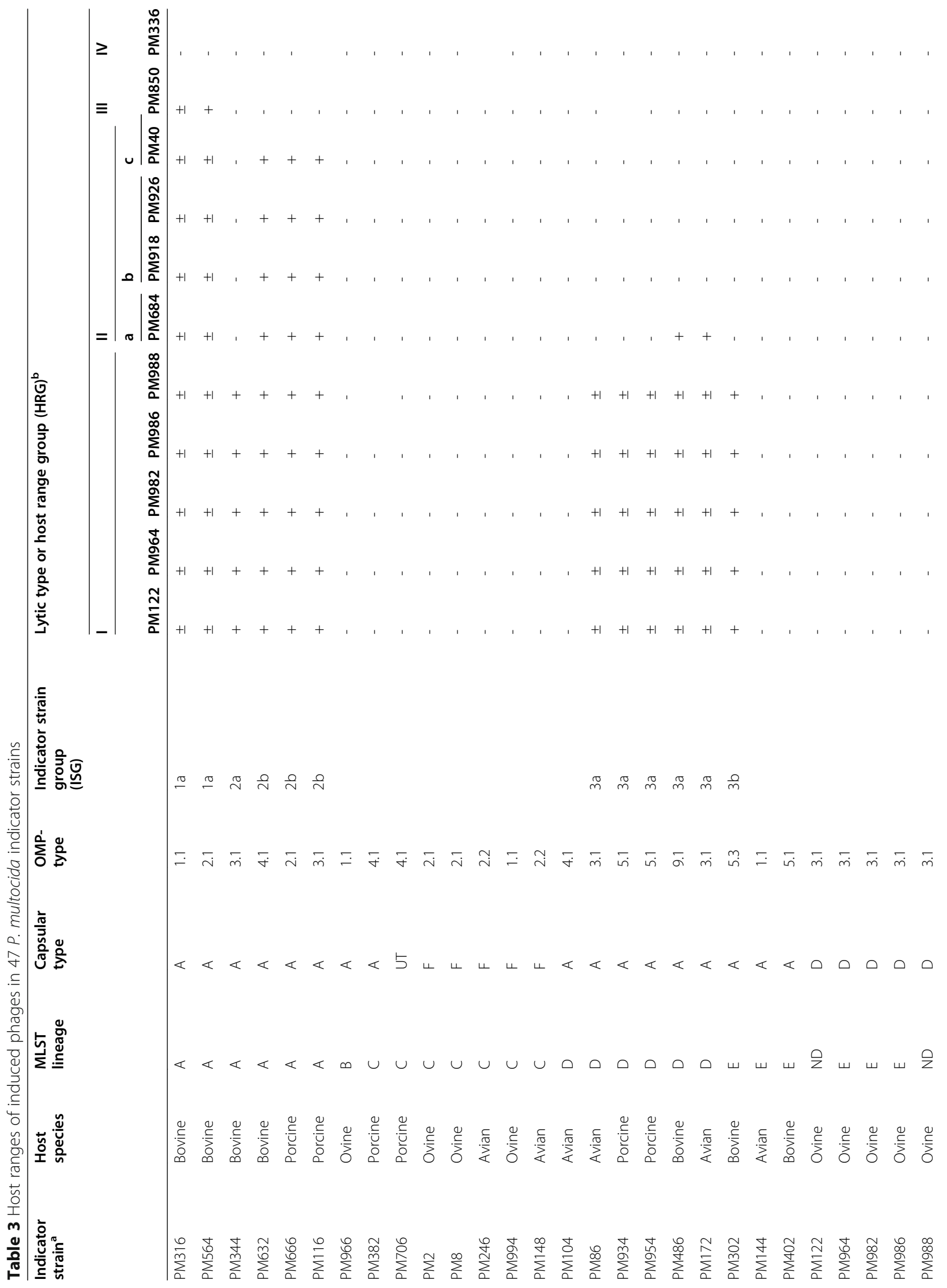




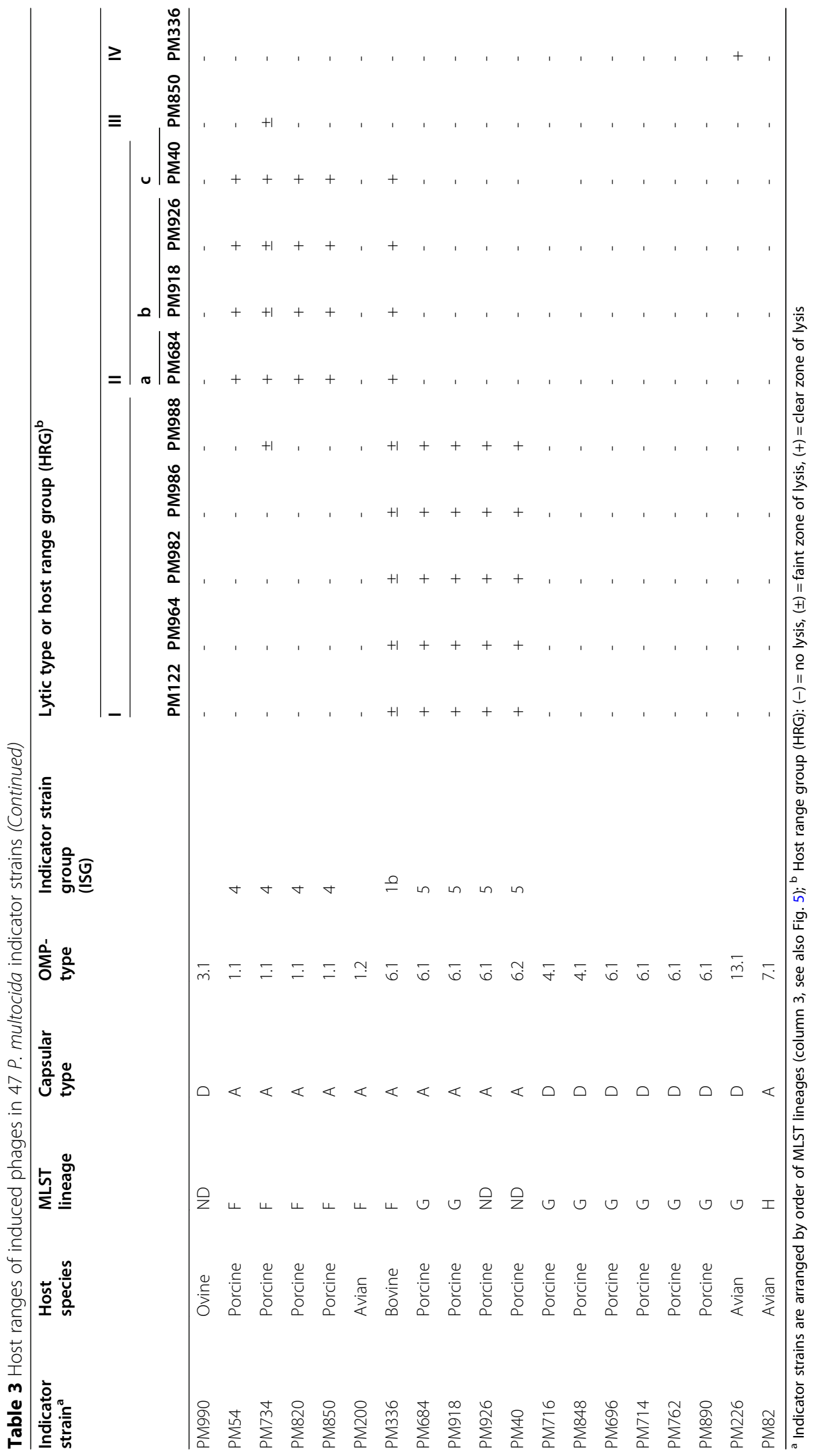


the sensitivity of strains to lysis by the various phage, and sensitive strains were assigned to "indicator strain groups" (ISGs) 1a, 1b, 2a, 2b, 3a, 3b, 4 and 5.

Lysates recovered from isolates PM122, PM964, PM982, PM986 and PM988 showed the broadest host range and represented HRG I. Notably, these phage were all Siphoviridae and of RE type C (Table 2) and were associated with closely-related ovine serotype D strains of OMP type 3.1 that represented a distinct cluster as part of lineage $\mathrm{E}$ on the phylogenetic tree (Table 3; Fig. 5). These phage caused lysis in 17 of 47 indicator strains and showed (with a single exception: PM964 lysate with indicator strain PM734) identical patterns of lysis (Table 3 ). The indicator strains that were sensitive to these phage lysates were represented by ISGs 1a (PM316, PM564), 1b (PM336), 2a (PM344), 2b (PM632, PM666, PM116), 3a (PM86, PM934, PM954 PM486, PM172), 3b (PM302), 4b (PM734) and 5 (PM684, PM918, PM926, PM40). Notably, there was a strong correlation between the strains representing each of these ISGs and the relatedness of the strains based on their phylogenies (Fig. 5), cell-surface characteristics (capsular serotype and OMP-types) and hosts of origin (Table 3). Thus, ISG 1a was associated with bovine serotype A isolates of lineage $\mathrm{A} 1$ whereas ISGs $2 \mathrm{a}$ and $2 \mathrm{~b}$ comprised bovine and porcine serotype A isolates of lineage A2; ISG 3a was associated with a cluster of avian, bovine and porcine serotype A isolates that comprised lineage D; and ISG 5 consisted of porcine serotype A isolates of lineage G. Notably, these latter strains of ISG 5 are all toxA-containing strains and represent a cluster (lineage G) that includes a high proportion of strains associated with atrophic rhinitis (Table 1 ).

Lysates recovered from isolates PM684, PM918, PM926 and PM40 also showed a broad host range and represented HRG IIa (PM684), IIb (PM918, PM926) and IIc (PM40). Notably, phage from each of these groups were represented by RE types F, G and $\mathrm{H}$, respectively, and were associated with closely-related porcine serotype A strains of OMP-type 6.1 (in the case of isolates PM684 and PM918) representing lineage G on the phylogenetic tree (Table 3; Fig. 5). These phage caused lysis in 10 of 47 indicator strains and showed similar, although not identical, patterns of lysis (Table 3). The indicator strains that were sensitive to these phage were represented by ISGs 1a (PM316, PM564), 1b (PM336), 2b (PM632, PM666, PM116), 4a (PM54, PM820, PM850) and 4b (PM734). Again, there was a strong correlation between the strains representing each of these ISGs and the relatedness of the strains based on their phylogenies (Fig. 5), cell-surface characteristics (capsular serotype and OMP-types) and hosts of origin (Table 3). The correlations for ISGs $1 \mathrm{a}$ and $2 \mathrm{~b}$ have been described above; ISGs $4 \mathrm{a}$ and $4 \mathrm{~b}$ were associated with porcine serotype A isolates of lineage F. Notably, these latter strains of ISG 4 belong to a cluster that is associated with porcine pneumonia (Fig. 5).

Lysates recovered from isolates PM850 and PM336 exhibited limited activity and represented HRGs III and IV, respectively. Interestingly, none of the phage lysates represented by RE type B (isolates PM934, PM954, PM486, PM172) were capable of lysing any of the indicator strains (Table 2). These phage were all of the Myoviridae type and were associated with the lineage D cluster of avian, bovine and porcine serotype A strains (Table 3, Fig. 5).

Overall, two observations among these results stood out above all others. First, it was highly significant that those nine isolates (PM122, PM982, PM986, PM988, PM964, PM684, PM918, PM926, PM40) representing HRGs I and II and with the broadest host ranges represent phylogenetically distinct ovine- and porcine-specific lineages and all contain the toxA gene (Table 1). Second, the possession of capsular type A was a feature common to all of the phage-sensitive indicator strains with a single exception; indeed there were only six serotype A strains that were insensitive to any of the phage lysates and none of the serotype $\mathrm{D}$ (with the single exception) or F strains exhibited sensitivity (Table 3). The single exception was an avian serotype D strain (PM226) that itself was sensitive to phage lysate from only a single isolate (PM336) (Table 3). Of particular relevance in this respect, closely related porcine strains of lineage G (Fig. 5) could be differentiated with respect to their capsular types and phage sensitivities; thus, serotype A strains were sensitive to phage of HRG 1 whereas serotype D strains were resistant.

\section{Discussion}

Pasteurella multocida is an important veterinary pathogen causing different types of infection in various host species. Temperate bacteriophages are involved in generating bacterial diversity and driving the emergence of new pathogenic strains by disseminating genes encoding virulence factors, such as toxins, via the mechanism of horizontal gene transfer [18, 27-30]. The aim of the present study was to assess the presence and diversity of temperate bacteriophages in a well-characterized and diverse collection of $P$. multocida strains of known genetic relatedness recovered from avian, bovine, ovine and porcine host species.

Different concentrations of mitomycin $\mathrm{C}$ have previously been used to induce temperate bacteriophages in other bacterial species [41,44, 45, 50-57] and we first set out to establish an optimum concentration for use with P. multocida. Eight isolates of avian, bovine, ovine and porcine origin (two each) and representing different 
disease syndromes, capsular serotypes, OMP-types and STs were selected for preliminary characterization. Initial experiments revealed that the effect of mitomycin $\mathrm{C}$ varied among the eight isolates with three different patterns being observed: complete lysis, partial lysis or reduced growth, and no lysis or no reduced growth (Fig. S1). Similar findings have been described previously in E. coli during the induction of $s t x_{2}$-converting bacteriophages with mitomycin C $[44,53]$. These preliminary experiments allowed an optimum mitomycin $\mathrm{C}$ concentration of $0.2 \mu \mathrm{g} / \mathrm{ml}$ to be established for the induction of temperate bacteriophages in $P$. multocida isolates. Subsequent induction of the $47 \mathrm{P}$. multocida isolates with mitomycin $C$ demonstrated that 15 (32\%) isolates exhibited complete lysis, 22 (47\%) were partially lysed or showed reduced growth, and $10(21 \%)$ showed no lysis. However, since mitomycin $\mathrm{C}$ can influence bacterial growth in other ways, such as by the induction of bacteriocins, which may also lead to cell death and lysis [58], it was important to confirm phage induction visually by TEM or by the recovery of phage DNA.

Transmission electron microscopy has been extensively used as a tool in the study of bacteriophage morphology, characterization and classification $[35,50]$. In the present study, temperate bacteriophages of different morphologies were identified by TEM in 29 P. multocida isolates. The phage particles identified belonged to the Siphoviridae (21 isolates) and Myoviridae (9 isolates) phage families although tail-less capsid particles (2 isolates) were also identified. A diverse set of temperate bacteriophages have previously been identified by TEM in P. multocida [35] as well as in the closely related species $M$. haemolytica [50]. Phage having diverse morphologies have also been identified in many other bacteria including Burkholderia [59], Clostridium [55, 60], Haemophilus [42], Lactobacillus [61], Listeria [62], Pseudomonas [63], Salmonella [64] and Yersinia [51]. Overall, the results showed that phage particles of similar morphotypes were associated with closely related isolates (i.e. with the same, or closely related, genetic lineage). For example, isolates PM122, PM964, PM982, PM986 and PM988 of lineage E possessed phage of similar Siphoviridae morphotypes; isolates PM86, PM172, PM486, PM934 and PM954 of lineage D contained phage of similar Myoviridae-like morphotypes. In some isolates (e.g. PM86, PM684 and PM850), both Siphoviridae- and Myoviridae-type phage were induced from the same bacterial host, suggesting that a single $P$. multocida isolate may harbour multiple prophages. The presence of multiple phage in a single bacterial host has not previously been described in $P$. multocida, although this is known to occur in other bacteria including $M$. haemolytica [40, 56], E. coli, Streptococcus pyogenes and Bacillus subtilis [65]. The identification of temperate bacteriophages in 29 isolates suggests that these phage are likely to play important and widespread roles in the diversification and evolution of $P$. multocida since it is well established that bacteriophages play significant roles in bacterial evolution [19, 27, 32, 66].

Although phage particles were identified by TEM in 29 P. multocida lysates, phage DNA could only be isolated from 18 of the associated lysates. The concentration of DNA recovered varied from 50 to $200 \mathrm{ng} / \mu \mathrm{l}$ suggesting that some isolates have higher rates of phage production (phage replication and release) than others. Notably, phage yielded by isolates that underwent complete lysis produced the highest concentrations of DNA, whereas phage yielded by isolates that underwent partial lysis produced lower DNA concentrations. Such variation in the amount of DNA recovered from induced phage has also been described in E. coli $[44,53]$. Classification of bacteriophages based on phage morphology has limitations because it does not provide information on genetic relatedness [67]. To overcome this problem, $\mathrm{RE}$ analysis of DNA has been used to assess the genetic diversity of induced phage in a wide-range of bacteria $[36,50,53,56,60,63,68]$. The identification of 10 different RE types in phage DNA recovered from only 18 isolates suggests that P. multocida bacteriophages are relatively diverse. As expected, multiple RE types were observed among phage having similar morphologies (i.e. Myoviridae or Siphoviridae) suggesting that phage of the same morphotypes are genetically divergent. Notably, RE types B, C and G were associated with two or more phage and phage of each RE type had identical morphologies (Table 2). Phage of RE type B had Myoviridaetype morphologies (and unusually small capsids), whereas phage of RE types C and G had Siphoviridaetype morphologies. Furthermore, phage representing each of these three RE types B, C and G were associated with closely-related isolates of lineages D, E and G, respectively (Fig. 5). Conversely, the association of more than one RE type with phage from isolates within the same lineage (e.g. RE types F [PM684], G [PM918, PM216] and I [PM848] of lineage G) suggests the presence of different phage types in closely related isolates; these isolates likely contain phage which have been acquired in recent phage-infection events. For example, isolate PM684 contains both Myoviridae- and Siphoviridae-type phage, whereas isolates PM918 and PM216 contain only a Siphoviridae-type phage, suggesting that the Myoviridae-type phage represents an additional acquisition. Clearly, further genomic analysis of the phage types associated with $P$. multocida is required to identify potential virulence genes that may be involved in the various disease syndromes caused by this pathogen.

Host range experiments were conducted using plaque assays to determine the presence of biologically active 
temperate bacteriophages and to assess the ability of induced phage to infect and lyse a range of indicator strains (Table 3). Overall, the plaque assays were less sensitive than TEM in determining the presence of phage in the lysates. Thus, of the 29 lysates that yielded phage particles (as determined by TEM), only 11 (38\%) lysates produced signs of infection in indicator strains. The low number of phage able to infect the indicator strains may have been due to the low number of indicator strains possessing appropriate cell surface-associated phage receptors. Attachment of phage to host cells is dependent on the ability of phage proteins to recognise specific binding or attachment sites (receptors) on the bacterial cell surface [69, 70]. Such receptors include outer membrane proteins such as OmpA, porins and LamB, LPS, pili and flagella [69-76]. Very little is known about phage receptors of $P$. multocida and further studies are required to identify these. Bacteriophages use different mechanisms to infect encapsulated bacteria and reach the bacterial cell surface because the capsule may block bacteriophage access to receptors localised in the cell wall $[69,70]$. Some phage produce capsular depolymerase enzymes that cause degradation of the capsular layer and allow the phage to reach the bacterial cell wall [69]. Therefore, it is probably significant that all but one of the phage-susceptible isolates was of capsular type A (Table 3). This capsular type might be acting directly as the phage receptor or it might be susceptible to a phagegenerated capsular depolymerase. The major component of the type A capsule is hyaluronic acid [77] and the type A capsule is known to be sensitive to hyaluronidase activity [78]. Thus, it would be interesting to speculate that many of these phage may possess hyaluronidase activity. Conversely, these observations might also reflect differences in phage tail fibre structure, or the complete absence of tail fibres, since the tail fibres are involved in the attachment of phage to receptors present on the bacterial cell surfaces $[69,70]$. Alternatively, some of these phage may have infected certain isolates and become incorporated into the bacterial genomes without causing lysis of these strains. In support of the latter hypothesis, temperate bacteriophages induced in Shiga-toxin producing $E$. coli were not detectable directly by plaque assay although these phage were detected by hybridisation [53]. Induced phage may also be unable to produce zones of lysis because certain prophages confer immunity via repressor proteins [56, 73].

Of the 11 phage lysates that caused infection of indicator strains, nine had relatively broad host ranges, infecting from 10 to 18 isolates (Table 3). These phage comprised two groups (HRGs I and II) which could be distinguished by their origins. Phage lysates of HRG I comprised Siphoviridae-type phage of RE type C which originated from ovine serotype D strains of lineage $\mathrm{E}$.
Phage lysates of HRG II were more diverse, representing three sub-groups, IIa, IIb and IIc; lysates of HRGs IIa, IIb and IIc comprised Myoviridae- and/or Siphoviridaetype phage of RE types F, G and H, respectively (Table 2). Phage of HRG II had similar origins in that they were recovered from porcine serotype A strains of lineage $G$ (Fig. 5). However, the most notable feature of these nine phage was that they all originated from ovine or porcine strains that possessed the toxA gene (Table 1). Pullinger et al. [36] demonstrated that toxA is associated with Siphoviridae-type phages in P. multocida and it is interesting to speculate that it is, perhaps, toxA-containing Siphoviridae-type phages that are responsible for the lysis of the indicator strains described herein. Indeed, subsequent genomic analysis of the phage DNA within these strains has shown that isolates PM122, PM964, PM982, PM986 and PM988 contain identical lambdalike Siphoviridae phage which are genetically distinct from identical lambda-like phage in isolates PM684, PM918, PM926 and PM940 (results not shown). Significantly, all nine phage sequences also contain the tox $A$ gene. The non-identity of these two phage groups also correlates with the differing host ranges of the phage lysates (Table 3). Thus, phage of HRG I lysed bacteria of ISGs $1 \mathrm{a}, 1 \mathrm{~b}, 2 \mathrm{a}, 2 \mathrm{~b}, 3 \mathrm{a}, 3 \mathrm{~b}$ and 5 whereas phage of HRG II lysed bacteria of ISGs 1a, 1b, 2b, 4a and 4b. Interestingly, none of these phage infected the same strains from which they originated, although phage of HRG I did infect the strains from which phage of HRG II were derived (Table 3).

Finally, five of the nine Myoviridae-type phage identified in the current study were unusual in that they all had a very distinct morphological appearance and were quite different from the other Myoviridae-type phage observed. These phage particles had unusually small hexagonal capsids and long tails compared to the other Myoviridae-type phage (Fig. 2f; Table 2). This phage type was induced exclusively in isolates PM86, PM172, PM486, PM934 and PM954 which belong to the same MLST cluster (i.e. lineage D, Fig. 5); isolates of this cluster were recovered from avian, bovine and porcine hosts. This type of Myoviridae-like phage, characterised by a small capsule and long tail, has not previously been described in $P$. multocida although phage of similar morphology have been identified in Clostridium difficile 027 strains [55] and in Bacillus species [79]. Phage particles with small capsids have also been identified as components of Staphylococcus aureus pathogenicity islands (SaPIs) [80]. SaPIs are phage-inducible chromosomal islands (PICIs) which maintain an intimate relationship with temperate helper bacteriophages. Following induction of the SOS response, the SaPI genome excises, replicates using its own replicon and encapsidates into small phage heads (to fit their smaller genome) 
produced by the helper phage $[80,81]$. The identification of Myoviridae-type phage particles with unusually small heads, together with the presence of two DNA bands representing two phage genomes of differing size (Fig. 3 ), strongly suggests the presence and induction of PICIs in P. multocida isolates PM86, PM172, PM486, PM934 and PM954. Indeed, this observation represents the first description of PICIs in P. multocida which has been confirmed elsewhere [82]. The exclusive association of PICIs and helper phage with closely-related isolates of lineage D suggests that they have been acquired, mostlikely by an ancestral strain, from an external source prior to the dissemination of these isolates to different host species.

\section{Conclusions}

The majority (79\%) of P. multocida isolates were sensitive to mitomycin $\mathrm{C}$ indicating that these isolates contain temperate bacteriophages. TEM subsequently identified a diverse set of phage in 29 induced cultures. The phage particles were morphologically diverse and represented the Siphoviridae and Myoviridae families. Both Siphoviridae- and Myoviridae-type phage were induced in certain isolates indicating that a single host may harbour multiple prophages. Moreover, a distinct Myoviridae phage type with an unusually small capsid was identified in certain isolates. The identification of 10 different RE profiles in the DNA of only 18 phage provided evidence that temperate bacteriophages in $P$. multocida are relatively diverse. Plaque assays were less sensitive than TEM for detection of temperate bacteriophages. Only 11 (38\%) phage lysates produced signs of infection against indicator strains and bacterial phage sensitivity was almost exclusively associated with strains of capsular type A. However, the majority (9/11) of phage lysates which caused infection originated from two groups of phylogenetically unrelated ovine and porcine strains that uniquely possessed the tox $A$ gene.

\section{Materials and methods}

\section{Bacterial isolates and growth conditions}

Forty-seven $P$. multocida isolates, obtained from regional laboratories of the UK Veterinary Laboratories Agency (VLA), were selected for characterization of their temperate bacteriophages. The isolates were recovered from cattle, sheep, pigs and poultry and were associated with different disease syndromes. They were selected to represent specific capsular serotypes types, OMPs-types and multilocus STs (Fig. 5) and have been well-characterised in previous studies $[9,46-49]$. The properties of the isolates are summarised in Table 1. The isolates were stored in $50 \%(\mathrm{v} / \mathrm{v})$ glycerol in brain heart infusion broth (BHIB; Oxoid) at $-80{ }^{\circ} \mathrm{C}$ and cultured on blood agar (brain heart infusion agar [BHIA; Oxoid] containing 5\% [v/v] defibrinated sheep's blood overnight at $37^{\circ} \mathrm{C}$. Liquid cultures were prepared by resuspending 3 to 4 well-isolated colonies (from an overnight plate culture) in $3 \mathrm{ml} \mathrm{BHIB}$ in a bijoux. Unless otherwise stated, $0.3 \mathrm{ml}$ of this suspension were used to inoculate $30-\mathrm{ml}$ prewarmed BHIB in a $100 \mathrm{ml}$ Erlenmeyer flask which was incubated at $37^{\circ} \mathrm{C}$ with shaking at $120 \mathrm{rpm}$.

\section{Induction and preparation of phage suspensions}

Bacteriophages were induced using a modification of a previously published procedure [50]. A final optimal concentration of $0.2 \mu \mathrm{g} / \mathrm{ml}$ mitomycin C (Sigma-Aldrich, UK) was determined in preliminary experiments using a panel of eight $P$. multocida strains. Briefly, two $30 \mathrm{ml}$ cultures of each isolate were inoculated and incubated as described above. Mitomycin $\mathrm{C}$ was added to one of each pair of flasks when the optical density $\left(\mathrm{OD}_{600}\right)$ reached 0.4 and the cultures were incubated for a further $8 \mathrm{~h}$. The rate of bacterial cell lysis (induction) was monitored by measuring the $\mathrm{OD}_{600}$ for both the mitomycin $\mathrm{C}$ treated and control cultures at hourly intervals. For those isolates which showed no signs of lysis after $8 \mathrm{~h}$, incubation was continued for $24 \mathrm{~h}$. In the absence of any signs of induction (i.e. no visible clearing in a specific isolate even after $24 \mathrm{~h}$ ), the experiment was repeated using higher concentrations of mitomycin $\mathrm{C}$ (i.e. 0.5, 1.0 and $2.0 \mu \mathrm{g} / \mathrm{ml}$ ). Bacteriophage induction was performed in triplicate for each isolate. The induction profile of each isolate was assigned (complete, partial or none) by comparing the $\mathrm{OD}_{600}$ values of mitomycin $\mathrm{C}$-treated and control cultures over the period of incubation. Phage suspensions were prepared by centrifuging the induced cultures at $4000 \mathrm{x} \mathrm{g}$ for $20 \mathrm{~min}$ at $4{ }^{\circ} \mathrm{C}$ to remove unlysed bacterial cells. The supernatants were carefully removed and filtered using $0.2 \mu \mathrm{m}$ pore-size syringe filters (Minisart) to remove bacterial debris. Filtered phage suspensions were either used immediately for host range determination or stored at $4{ }^{\circ} \mathrm{C}$ for further characterization and analysis.

\section{Transmission electron microscopy}

Ten millilitres of each filtered phage suspension were centrifuged at $40,000 \mathrm{x} \mathrm{g}$ for $90 \mathrm{~min}$ at $4{ }^{\circ} \mathrm{C}$. The supernatants were carefully removed and the pellets resuspended gently in $0.5 \mathrm{ml}$ of $0.1 \mathrm{M}$ ammonium acetate ( $\mathrm{pH}$ 7.3). The suspensions were stored overnight at $4{ }^{\circ} \mathrm{C}$ for negative staining and vizualisation by TEM. Three hundred-mesh carbon-coated nickel grids were dropped onto $50-100 \mu \mathrm{l}$ of phage suspension. The grids were allowed to adsorb phage suspension for 1-2 min and were washed three times with $\mathrm{dH}_{2} \mathrm{O}$ for $10 \mathrm{~s}$. Excess fluid was removed using Whatman filter paper and the grids were negatively stained with $2 \%$ ammonium molybdate for $30 \mathrm{~s}$. Excess staining solution was removed 
with Whatman filter paper and the grids allowed to airdry at room temperature for 15 to $20 \mathrm{~min}$. The samples were examined by TEM using a FEI Tecnai TF20 electron microscope at $200 \mathrm{kV}$ and Gatan Microscopy Suite Software.

\section{Phage purification and DNA extraction}

To obtain sufficient numbers of phage particles for DNA extraction, bacteria were grown in $50 \mathrm{ml}$ volumes of BHIB in $250 \mathrm{ml}$ Erlenmeyer flasks prior to induction of bacteriophages. After induction, the bacteria were removed by centrifugation and filtration as described above and the filtered lysates stored at $4{ }^{\circ} \mathrm{C}$. Phage DNA was obtained by the standard method described for bacteriophage lambda DNA [83]. Briefly, $40 \mathrm{ml}$ of filtered lysate were transferred into sterile $50 \mathrm{ml}$ centrifuge tubes and allowed to reach room temperature. DNase (SigmaAldrich, UK, Cat.No.D4263) and RNase (Sigma-Aldrich, UK, Cat.No. R4642) were added to final concentrations of $10 \mu \mathrm{g} / \mathrm{ml}$ and incubated for $1 \mathrm{~h}$ at $37^{\circ} \mathrm{C}$. Solid $\mathrm{NaCl}$ (Fisher Scientific, UK) was added to a final concentration of $1 \mathrm{M}$. The mixture was dissolved and left to stand for $1 \mathrm{~h}$ on ice. Bacterial debris was removed by centrifugation at $11,000 \times \mathrm{g}$ for $10 \mathrm{~min}$ at $4{ }^{\circ} \mathrm{C}$ and the supernatants collected into clean centrifuge tubes. The phage particles were concentrated by adding polyethylene glycol (PEG 8000; Sigma-Aldrich, UK) to a final concentration of $10 \%(\mathrm{w} / \mathrm{v})$. The PEG 8000 was slowly dissolved by stirring and the treated mixture allowed to stand on ice for $1 \mathrm{~h}$. Precipitated phage particles were recovered by centrifugation at $11,000 \mathrm{x}$ g for $15 \mathrm{~min}$ at $4{ }^{\circ} \mathrm{C}$. The supernatants were carefully removed and the tubes left to dry for $10 \mathrm{~min}$ at room temperature. Finally, the pelleted phage particles were re-suspended in $200 \mu \mathrm{l}$ phage buffer $\left(0.1 \mathrm{M} \mathrm{MgSO}_{4}, 1 \mathrm{M} \mathrm{CaCl}_{2}, 2.95 \mathrm{~g}\right.$ of $\mathrm{NaCl}, 2.5 \mathrm{M}$ Tris, $\mathrm{pH} 8$ ) and stored at $4{ }^{\circ} \mathrm{C}$ for DNA extraction. To each aliquot of re-suspended phage, $200 \mu \mathrm{l}$ of lysis mix were added ( $19 \mu \mathrm{l}$ of $20 \%$ SDS [Sigma-Aldrich, UK], $9 \mu \mathrm{l}$ of proteinase $\mathrm{K}[20 \mathrm{mg} / \mathrm{ml}$; Promega] and $172 \mu \mathrm{l}$ of $\mathrm{dH}_{2} \mathrm{O}$ ) and the mixture incubated at $56^{\circ} \mathrm{C}$ for $1 \mathrm{~h}$. Phenol-chloroform-isoamyl alcohol (25:24:1; SigmaAldrich, UK) extraction and ethanol precipitation were used to extract the phage DNA as previously described [83]. The DNA was recovered by centrifugation at 13 , $000 \mathrm{x} \mathrm{g}$ for $1 \mathrm{~min}$ at $4{ }^{\circ} \mathrm{C}$ and its concentration measured using a NanoDrop 2000C spectrophotometer (Thermo Scientific). Purified phage DNA was separated by agarose gel electrophoresis and visualised with Syber $^{\circ}$ Safe DNA gel stain (Invitrogen). The DNA was stored at $20^{\circ} \mathrm{C}$.

\section{Restriction endonuclease analysis}

The genetic relatedness of the phage induced in $P$. multocida was assessed by RE analysis using the restriction enzymes PsI, BamH1, Hind III, Ndel, EcoR1 and XbaI (New England Biolabs Ltd., UK) according to the manufacturer's instructions. Briefly, the final $20 \mu \mathrm{l}$ reaction mixtures contained DNA $(1 \mu \mathrm{g} / \mu \mathrm{l})$, restriction enzyme $(1 \mu \mathrm{l})$ and cut smart buffer $(2 \mu \mathrm{l})$, and the reactions were incubated at $37^{\circ} \mathrm{C}$ for $4 \mathrm{~h}$. In some experiments digestion was performed overnight at $37^{\circ} \mathrm{C}$. Digested phage DNA was separated by agarose gel electrophoresis and visualised with Syber ${ }^{\circ}$ Safe DNA gel stain (Invitrogen). The size of the DNA bands was estimated using a $1 \mathrm{~kb}$ plus DNA ladder (Invitrogen).

\section{Bacteriophage host range}

The ability of induced phage to infect $P$. multocida indicator strains was assessed using the double agar overlay plaque assay. The host range of phage induced in 29 isolates was examined against all $47 \mathrm{P}$. multocida isolates. The indicator strains were grown overnight in BHIB at $37^{\circ} \mathrm{C}$ with shaking at $120 \mathrm{rpm}$. Overlay plates were prepared using a base layer of $1 \%$ BHIA and a top layer of soft agar comprising BHIB, 0.7\% (w/v) Microagar (Duchenne, London, UK) and $2 \mathrm{mM} \mathrm{CaCl}$ (PROLABO). The semi-solid medium (BHIB $+0.7 \%$ microagar) and $\mathrm{CaCl}_{2}(1 \mathrm{M})$ were autoclaved separately at $120^{\circ} \mathrm{C}$ for 15 min to prevent precipitation. The semi-solid medium was cooled to $56^{\circ} \mathrm{C}$ and the $\mathrm{CaCl}_{2}(1 \mathrm{M})$ added to a final concentration of $2 \mathrm{mM}$. The molten soft agar was held in a water bath at $48^{\circ} \mathrm{C}$ to avoid solidification. Bacterial lawns were prepared by adding $50 \mu \mathrm{l}$ of broth cultures to $3 \mathrm{ml}$ of warm molten soft agar in a bijoux. Bacteria and agar were mixed and poured immediately onto the surface of the dried base layers with gentle rocking. The top layers were allowed to solidify and dried at room temperature for 15 to $20 \mathrm{~min}$. Ten microlitres of each filtered phage suspension were spotted onto dried plates seeded with each of the 47 indicator strains. The plates were allowed to dry for $20-30 \mathrm{~min}$ and incubated at $37^{\circ} \mathrm{C}$ for $24 \mathrm{~h}$ before assessment of bacterial lysis. The interaction of each phage/indicator strain combination was assessed in triplicate.

\section{Supplementary Information}

The online version contains supplementary material available at https://doi. org/10.1186/s12866-021-02155-9.

\section{Additional file 1.}

\section{Acknowledgements}

We would like to thank Margaret Mullin, Senior Technician, Electron Microscopy Facility, School of Life Sciences, MVLS for the EM imaging.

Authors' contributions

Rezheen F. Abdulrahman and Robert L. Davies designed the study. Rezheen F. Abdulrahman performed the experiments, data analysis and drafted the manuscript under supervision of Robert L. Davies. Robert L. Davies helped 
with the data analysis and revised the manuscript. All authors read and approved the final manuscript.

\section{Funding}

This work was supported by Ministry of Higher Education and Scientific Research/ Kurdistan Region / Iraq as part of HCDP scholarship program.

\section{Availability of data and materials}

Not applicable.

\section{Declarations}

Ethics approval and consent to participate

Not applicable.

\section{Consent for publication}

Not applicable.

\section{Competing interests}

No competing interests.

\section{Author details}

${ }^{1}$ Institute of Infection, Immunity and Inflammation, College of Medical, Veterinary and Life Sciences, Sir Graeme Davies Building, University of Glasgow, 120 University Place, Glasgow G12 8TA, UK. Pathology and Microbiology Department, Collage of Veterinary Medicine, University of Duhok, Kurdistan Region, Iraq.

\section{Received: 9 September 2020 Accepted: 25 February 2021}

Published online: 30 March 2021

\section{References}

1. Rimler RB, Rhoades KR. Pasteurella multocida. In: Adlam C, Rutter JM, editors. Pasteurella and Pasteurellosis. London: Academic press Limited; 1989. p. 37-73.

2. Saif YM. Diseases of poultry. Ames: Wiley-Blackwell; 2008.

3. Mohamed MA, Mohamed MWA, Ahmed Al. Pasteurella multocida in backyard chickens in upper Egypt: incidence with polymerase chain reaction analysis for capsule type, virulence in chicken embryos and antimicrobial resistance. Vet Ital. 2012;48(1):77-86.

4. Carter GR, De Alwis MCL. Haemorrhagic Septicaemia. In: Adlam C, Rutter JM, editors. Pasteurella and Pasteurellosis. London: Academic press Limited; 1989. p. 131-60.

5. Chanter N, Rutter JM. Pasteurellosis in pigs and the determinants of virulence of toxigenic Pasteurella multocida. In: Adlam C, Rutter JM, editors Pasteurella and Pasteurellosis. London: Academic press Limited; 1989. p. 161-95.

6. Orth JHC, Aktories K. Pasteurella multocida toxin activates various heterotrimeric G proteins by deamidation. Toxins (Basel). 2010;2(2):205-14. https://doi.org/10.3390/toxins2020205.

7. Kloos B, Chakraborty S, Lindner SG, Noack K, Harre U, Schett G, et al. Pasteurella multocida toxin- induced osteoclastogenesis requires mTOR activation. Cell Commun Signal. 2015;1:1-13.

8. Frank GJ. Pasteurellosis of cattle. In: Adlam C, Rutter JM, editors. Pasteurella and Pasteurellosis. London: Academic press Limited; 1989. p. 197-222.

9. Davies RL, Watson J, Caffrey B. Comparative analyses of Pasteurella multocida strains associated with the ovine respiratory and vaginal tracts. Vet Rec. 2003;152(1):7-10. https://doi.org/10.1136/vr.152.1.7.

10. Manning PJ, DiGiacomo RF, DeLong D. Pasteurellosis in laboratory animals. In: Adlam C, Rutter JM, editors. Pasteurella and Pasteurellosis. London: Academic press Limited; 1989. p. 264-302.

11. Watson PJ, Davies RL. Outbreak of Pasteurella multocida septicaemia in neonatal lambs. Vet rRec. 2002;151(14):420-2. https://doi.org/10.1136/vr.1 51.14.420.

12. Rad M, Movassaghi AR, Sharifi K, Naseri Z, Seifi HA. Two outbreaks of Pasteurella multocida septicemia in neonatal lambs. Comp Clin Pathol. 2011; 20:57-9.

13. Frederiksen W. Pasteurellosis of Man. In: Rutter CA\& JM, editor. Pasteurella and Pasteurellosis. UK: Academic press Limited; 1989. p. 303-320.
14. Freshwater A. Why your housecat's trite little bite could cause you quite a fright: a study of domestic felines on the occurrence and antibiotic susceptibility of Pasteurella multocida. Zoonoses Public Heal. 2008;55:507-13.

15. Oehler RL, Velez AP, Mizrachi M, Lamarche J, Gompf S. Bite-related and septic syndromes caused by cats and dogs. Lancet Infec Dise. 2009;9(7): 439-47. https://doi.org/10.1016/\$1473-3099(09)70110-0.

16. Harper M, Boyce JD, Adler B. Pasteurella multocida pathogenesis: 125 years after Pasteur. FEMS Microbiol Lett. 2006;265(1):1-10. https://doi.org/10.1111/ j.1574-6968.2006.00442.x.

17. Fernandez S, Galapero J, Gomez L, Perez CJ, Ramos A, Cid D, Garcia A, Rey J. Identification, capsular typing and virulence factors of Pasteurella multocida isolates from merino lambs in Extremadura (southwestern Spain). Vet Med (Praha). 2018;63(3):117-24. https://doi.org/10.17221/142/2016-VETMED.

18. Saunders JR, Allison H, James CE, McCarthy AJ, Sharp R. Phage-mediated transfer of virulence genes. J Chem Technol Biotechnol. 2001;76(7):662-6. https://doi.org/10.1002/jctb.437.

19. Brüssow H, Canchaya C, Hardt W. Phages and the evolution of bacterial pathogens: from genomic rearrangements to lysogenic conversion. Micr Mol Bio Rev. 2004:68(3):560-602. https://doi.org/10.1128/MMBR.68.3.560602.2004

20. Dearborn AD, Dokland T. Mobilization of pathogenicity islands by Staphylococcus aureus strain Newman bacteriophages. Bacteriophage. 2012 2(2):70-8. https://doi.org/10.4161/bact.20632.

21. Busby B, Kristensen DM, Koonin EV. Contribution of phage-derived genomic islands to the virulence of facultative bacterial pathogens. Physiol Behav. 2017:176:139-48.

22. Fortier L-C, Sekulovic O. Importance of prophages to evolution and virulence of bacterial pathogens. Virulence. 2013;4(5):354-65. https://doi. org/10.4161/viru.24498.

23. Davies EV, Winstanley C, Fothergill JL, James CE. The role of temperate bacteriophages in bacterial infection. FEMS Microbiol Lett. 2016:363:1-10.

24. Kraushaar B, Hammerl JA, Kienöl M, Heinig ML, Sperling N, Thanh MDi, et al. Acquisition of virulence factors in livestock-associated MRSA: lysogenic conversion of CC398 strains by virulence gene-containing phages. Sci Rep. 2017;7:1-13.

25. Feiner R, Argov T, Rabinovich L, Sigal N, Borovok I, Herskovits AA. A new perspective on lysogeny: prophages as active regulatory switches of bacteria. Natu Rev Microbiol. 2015;13(10):641-50. https://doi.org/10.1038/ nrmicro3527.

26. Veses-Garcia M, Liu X, Rigden DJ, Kenny JG, McCarthy AJ, Allison HE. Transcriptomic analysis of Shiga-toxigenic bacteriophage carriage reveals a profound regulatory effect on acid resistance in Escherichia coli. Appl Env Microbiol. 2015;81(23):8118-25. https://doi.org/10.1128/AEM.02034-15.

27. Boyd EF, Brüssow H. Common themes among bacteriophage-encoded virulence factors and diversity among the bacteriophages involved. Trends Microbiol. 2002;10(11):521-9. https://doi.org/10.1016/S0966-842X(02)02459-9.

28. Boyd EF. Bacteriophage-encoded bacterial virulence factors and phagepathogenicity island interactions. Adv Virus Res. 2012;82:91-118. https://doi. org/10.1016/B978-0-12-394621-8.00014-5.

29. Penadés JR, Chen J, Quiles-Puchalt N, Carpena N, Novick RP. Bacteriophagemediated spread of bacterial virulence genes. Curr Opin Microbiol. 2015;23: 171-8. https://doi.org/10.1016/j.mib.2014.11.019.

30. Allison HE. Stx-phages : drivers and mediators of the evolution of STEC and STEC-like pathogens. Future Microbiol. 2007;2(2):165-74. https://doi.org/1 0.2217/17460913.2.2.165.

31. Cheetham BF, Katz ME. A role for bacteriophages in the evolution and transfer of bacterial virulence determinants. Mol Microbiol. 1995;18(02):2018. https://doi.org/10.1111/j.1365-2958.1995.mmi_18020201.x.

32. Masignani V, Giuliani MM, Tettelin H, Comanducci M, Rappuoli R, Scarlato V. Mu-like prophage in serogroup B Neisseria meningitidis coding for surfaceexposed antigens. Infec Immun. 2001;69(4):2580-8. https://doi.org/10.1128/ |Al.69.4.2580-2588.2001.

33. Nielsen JP, Rosdahl VT. Development and epidemiological applications of a bacteriophage typing system for typing Pasteurella multocida. J Clin Microbiol. 1990;28(1):103-7. https://doi.org/10.1128/JCM.28.1.103-107.1990.

34. Fussing V, Nielsen JP, Bisgaard M, Meyling A. Development of a typing system for epidemiological studies of porcine toxin-producing Pasteurella multocida ssp. multocida in Denmark. Vet Microbio. 1999;65(1):61-74. https://doi.org/10.1016/S0378-1135(98)00288-0.

35. Ackermann HW, Karaivanov L. Morphology of Pasteurella multocida bacteriophages. Can J Microbiol. 1984;30(9):1141-8. https://doi.org/10.1139/ m84-179. 
36. Pullinger GD, Bevir T, Lax AJ. The Pasteurella multocida toxin is encoded within a lysogenic bacteriophage. Mol Microbiol. 2004;51(1):255-69. https:// doi.org/10.1046/j.1365-2958.2003.03829.x.

37. Shayegh J, Atashpaz S, Hejazi MS. Virulence genes profile and typing of ovine 380 Pasteurella multocida. Asian J Anim Vet Adv. 2008;3(4):206-13. https://doi.org/10.3923/ajava.2008.206.213.

38. Einarsdottir T, Gunnarsson E, Sigurdardottir OG, Jorundsson E, Fridriksdottir $\mathrm{V}$, Thorarinsdottir GE, et al. Variability of Pasteurella multocida isolated from icelandic sheep and detection of the toxA gene. J Med Microbiol. 2016; 65(9):897-904. https://doi.org/10.1099/jmm.0.000306

39. Goerke C, Koller J, Wolz C. Ciprofloxacin and trimethoprim cause phage induction and virulence modulation in Staphylococcus aureus. Antimic Agents Chemoth. 2006;50(1):171-7. https://doi.org/10.1128/AAC.50.1.171-177.2006.

40. Niu YD, Cook SR, Wang J, Klima CL, Hsu Y, Kropinski AM, Turner D, McAllister TA. Comparative analysis of multiple inducible phages from Mannheimia haemolytica. BMC Microbiol. 2015;15(1):175. https://doi.org/1 0.1186/s12866-015-0494-5.

41. Shin H, Lee J-H, Yoon H, Kang D-H, Ryu S. Genomic investigation of lysogen formation and host lysis systems of the Salmonella temperate bacteriophage SPN9CC. Appl Env Microbiol. 2014;80(1):374-84. https://doi. org/10.1128/AEM.02279-13

42. Williams BJ, Golomb M, Phillips T, Brownlee J, Olson MV, Smith AL. Bacteriophage HP2 of Haemophilus influenzae. J Bacteriol. 2002;184(24): 6893-905. https://doi.org/10.1128/JB.184.24.6893-6905.2002

43. Campoy S, Aranda J, Àlvarez G, Barbé J, Llagostera M. Isolation and sequencing of a temperate transducing phage for Pasteurella multocida. Appl Env Microbiol. 2006;72(5):3154-60. https://doi.org/10.1128/AEM.72.5.31 54-3160.2006

44. Muniesa M, De Simon M, Prats G, Ferrer D, Pañella H, Jofre J. Shiga toxin 2converting bacteriophages associated with clonal variability in Escherichia coli 0157 : H7 strains of human origin isolated from a single outbreak. Infec Immun. 2003;71(8):4554-62. https://doi.org/10.1128/IAl.71.8.4554-4562.2003.

45. Oliveira J, Mahony J, Hanemaaijer L, Kouwen TRHM, Neve H, MacSharry J, et al. Detecting Lactococcus lactis prophages by mitomycin C-mediated induction coupled to flow cytometry analysis. Front Microbio. 2017:8:1-11.

46. Davies RL, MacCorquodale R, Baillie S, Caffrey B. Characterization and comparison of Pasteurella multocida strains associated with porcine pneumonia and atrophic rhinitis. J Med Microbiol. 2003;52(1):59-67. https:// doi.org/10.1099/jmm.0.05019-0.

47. Davies RL, MacCorquodale R, Caffrey B. Diversity of avian Pasteurella multocida strains based on capsular PCR typing and variation of the OmpA and OmpH outer membrane proteins. Vet Microbiol. 2003;91(2-3):169-82. https://doi.org/10.1016/S0378-1135(02)00300-0.

48. Davies RL. Genetic diversity among Pasteurella multocida strains of avian, bovine, ovine and porcine origin from England and Wales by comparative sequence analysis of the 16S rRNA gene. Microbiol. 2004;150(12):4199-210. https://doi.org/10.1099/mic.0.27409-0.

49. Davies RL, MacCorquodale R, Reilly S. Characterisation of bovine strains of Pasteurella multocida and comparison with isolates of avian, ovine and porcine origin. Vet Microbiol. 2004;99(2):145-58. https://doi.org/10.1016/j. vetmic.2003.11.013.

50. Davies $\mathrm{RL}$, Lee I. Diversity of temperate bacteriophages induced in bovine and ovine Mannheimia haemolytica isolates and identification of a new P2like phage. FEMS Microbiol Lett. 2006;260(2):162-70. https://doi.org/10.1111/ j.1574-6968.2006.00314.x.

51. Stevenson RM, Airdrie DW. Isolation of Yersinia ruckeri bacteriophages. Appl Env Microbiol. 1984;47(6):1201-5. https:/doi.org/10.1128/AEM.47.6.1201-1205.1984.

52. Poblet-Icart M, Bordons A, Lonvaud-Funel A. Lysogeny of Oenococcus oeni (syn. Leuconostoc oenos) and study of their induced bacteriophages. Curr Microbiol. 1998:36(6):365-9. https://doi.org/10.1007/s002849900324.

53. Muniesa M, Blanco JE, De Simón M, Serra-Moreno R, Blanch AR, Jofre J. Diversity of stx2 converting bacteriophages induced from Shiga-toxinproducing Escherichia coli strains isolated from cattle. Microbiol. 2004;150(Pt 9):2959-71. https://doi.org/10.1099/mic.0.27188-0.

54. Highlander SK, Weissenberger S, Alvarez LE, Weinstock GM, Berget PB. Complete nucleotide sequence of a P2 family lysogenic bacteriophage, varphiMhaA1-PHL101, from Mannheimia haemolytica serotype A1. Virol. 2006:350(1):79-89. https://doi.org/10.1016/j.virol.2006.03.024

55. Nale JY, Shan J, Hickenbotham PT, Fawley WN, Wilcox MH, Clokie MRJ. Diverse temperate bacteriophage carriage in Clostridium difficile 027 strains. PLoS One. 2012;7(5):e37263. https://doi.org/10.1371/journal.pone.0037263.
56. Hsu Y-H, Cook SR, Alexander TW, Klima CL, Niu YD, Selinger LB, McAllister TA. Investigation of Mannheimia haemolytica bacteriophages relative to host diversity. J App Microbiol. 2013;114(6):1592-603. https://doi.org/10.1111/ja m.12185.

57. Urban-Chmiel R, Wernicki A, Stęgierska D, Dec M, Dudzic A, Puchalski A. Isolation and characterization of lytic properties of bacteriophages specific for M haemolytica strains. PLoS One. 2015;10:e0140140.

58. Bradley DE. Ultrastructure of bacteriophage and bacteriocins. Bacteriol Rev. 1967;31(4):230-314. https://doi.org/10.1128/BR.31.4.230-314.1967.

59. Seed KD, Dennis JJ. Isolation and characterization of bacteriophages of the Burkholderia cepacia complex. FEMS Microbiol Lett. 2005;251(2):273-80. https://doi.org/10.1016/j.femsle.2005.08.011.

60. Sekulovic O, Garneau JR, Neron A, Fortier LC. Characterization of temperate phages infecting Clostridium difficile isolates of human and animal origins. Appl Env Microbiol. 2014;80(8):2555-63. https://doi.org/10.1128/AEM.0023 7-14.

61. Kiliç AO, Pavlova SI, Alpay S, Kiliç SS, Tao L. Comparative study of vaginal Lactobacillus phages isolated from women in the United States and Turkey: prevalence, morphology, host range, and DNA homology. Clin Diagn Lab Immunol. 2001;8:31-9.

62. Denes T, Vongkamjan K, Ackermann HW, Moreno Switt Al, Wiedmann M, den Bakker HC. Comparative genomic and morphological analyses of Listeria phages isolated from farm environments. Appl Env Microbiol. 2014; 80(15):4616-25. https://doi.org/10.1128/AEM.00720-14.

63. Sepúlveda-Robles O, Kameyama L, Guarneros G. High diversity and novel species of Pseudomonas aeruginosa bacteriophages. Appl Env Microbiol. 2012;78(12):4510-5. https://doi.org/10.1128/AEM.00065-12.

64. Moreno Switt Al, Orsi RH, den Bakker HC, Vongkamjan K, Altier C, Wiedmann M. Genomic characterization provides new insight into Salmonella phage diversity. BMC Genomics. 2013;14(1):481. https://doi.org/1 0.1186/1471-2164-14-481.

65. Canchaya C, Proux C, Fournous G, Bruttin A, Brüssow H. Prophage genomics. Microbiol Mol Biol Rev. 2003;67(2):238-76. https://doi.org/10.112 8/MMBR.67.2.238-276.2003.

66. Ventura M, Canchaya C, Kleerebezem M, De Vos WM, Siezen RJ, Brüssow H. The prophage sequences of Lactobacillus plantarum strain WCFS1. Virology. 2003;316(2):245-55. https://doi.org/10.1016/j.virol.2003.08.019.

67. Lawrence JG, Hatfull GF, Hendrix RW. Imbroglios of viral taxonomy: genetic exchange and failings of phenetic approaches. J Bacteriol. 2002;184(17): 4891-905. https://doi.org/10.1128/JB.184.17.4891-4905.2002.

68. Jakhetia R, Verma NK. Identification and molecular characterisation of a novel mu-like bacteriophage, SfMu, of Shigella flexneri. PLoS One. 2015;10(4): e0124053. https://doi.org/10.1371/journal.pone.0124053.

69. Lindbergl AA. Bacteriophage receptors. Annu Rev Microbiol. 1973;27(1):20541. https://doi.org/10.1146/annurev.mi.27.100173.001225.

70. Rakhuba DV, Kolomiets El, Dey ES, Novik Gl. Bacteriophage receptors, mechanisms of phage adsorption and penetration into host cell. Pol J Microbiol. 2010;59(3):145-55. https://doi.org/10.33073/pjm-2010-023.

71. Randall-Hazelbauer $\mathrm{L}$, Schwartz M. Isolation of the bacteriophage lambda receptor from Escherichia coli. J Bacteriol. 1973;116(3):1436-46. https://doi. org/10.1128/JB.116.3.1436-1446.1973.

72. Morona R, Kramer C, Henning ULF. Bacteriophage receptor area of outer membrane protein OmpA of Escherichia coli K-12. J Bacteriol. 1985;164(2): 539-43. https://doi.org/10.1128/JB.164.2.539-543.1985.

73. Guttman B, Raya R, Kutter E. Basic phage biology. In: Kutter, E. and Sulakvelidze A, editor. Bacteriophages: Biology and Applications. Boca Raton: CRC Press; 2005. p. 28-66.

74. Parent KN, Erb ML, Cardone G, Nguyen K, Gilcrease EB, Porcek NB, Pogliano J, Baker TS, Casjens SR. OmpA and OmpC are critical host factors for bacteriophage Sf6 entry in Shigella. Mol Microbiol. 2014;92(1):47-60. https:// doi.org/10.1111/mmi.12536.

75. Jin Y, Sdao SM, Dover JA, Porcek NB, Knobler CM, Gelbart WM, Parent KN. Bacteriophage P22 ejects all of its internal proteins before its genome. Virology. 2015;485:128-34. https://doi.org/10.1016/j.virol.2015.07.006.

76. Porcek NB, Parent KN. Key residues of S. flexneri OmpA mediate infection by bacteriophage Sf6. Mol Biol. 2015;427(10):1964-76. https://doi.org/10.1016/j. jmb.2015.03.012

77. Rosner H, Grimmecke H, Knirel Y, Shashkov A. Hyaluronic acid and a (1-4)$\beta$-D-xylan, extracellular polysaccharides of Pasteurella multocida (Carter type a) strain 880. Carbohydr Res. 1992;223:329-33. https://doi.org/10.1016/00086215(92)80032-V. 
78. Carter GR. Some characteristics of type a strains of Pasteurella multocida. Brit Vet J. 1958;1 14(9):356-7. https://doi.org/10.1016/S0007-1935(17)45256-0.

79. Bfudley BYDE. The isolation and morphology of some new bacteriophages specific for Bacillus and Acetobacter species. J Gen Microbiol. 1965;41:233-41.

80. Úbeda C, Maiques E, Knecht E, Lasa Í, Novick RP, Penadés JR. Antibioticinduced SOS response promotes horizontal dissemination of pathogenicity island-encoded virulence factors in Staphylococci. Mol Microbiol. 2005;56(3): 836-44. https://doi.org/10.1111/j.1365-2958.2005.04584.x.

81. Tormo MÁ, Ferrer MD, Maiques E, Úbeda C, Selva L, Lasa Í, et al. Staphylococcus aureus pathogenicity island DNA is packaged in particles composed of phage proteins. J Bacteriol. 2008;190(7):2434-40. https://doi. org/10.1128/JB.01349-07.

82. Fillol-Salom A, Martínez-Rubio R, Abdulrahman RF, Chen O, Davies R, Penadés JR. Phage-inducible chromosomal islands are ubiquitous within the bacterial universe. ISME J. 2018;12(9):2114-28. https://doi.org/10.1038/s413 96-018-0156-3.

83. Sambrook J, Fristch EF, Maniatis T. Molecular cloning, a laboratory manual. 2nd ed. Cold Spring Harbor, New York: Cold Spring Harbor Laboratory Press; 1989

\section{Publisher's Note}

Springer Nature remains neutral with regard to jurisdictional claims in published maps and institutional affiliations.

Ready to submit your research? Choose BMC and benefit from:

- fast, convenient online submission

- thorough peer review by experienced researchers in your field

- rapid publication on acceptance

- support for research data, including large and complex data types

- gold Open Access which fosters wider collaboration and increased citations

- maximum visibility for your research: over $100 \mathrm{M}$ website views per year

At $\mathrm{BMC}$, research is always in progress.

Learn more biomedcentral.com/submissions 